\title{
Alternating high and low climate variability: the context of natural selection and speciation in Plio-Pleistocene hominin evolution
}

Richard Potts ${ }^{\mathrm{a}, *}$, J. Tyler Faith ${ }^{\mathrm{b}}$

${ }^{a}$ Human Origins Program, National Museum of Natural History, Smithsonian Institution, Washington, DC 20013-7012, USA; Department of Earth Sciences, National Museums of Kenya, P.O. Box 40658-00100, Nairobi, Kenya

${ }^{\mathrm{b}}$ School of Social Science, Archaeology Program, University of Queensland, Brisbane QLD 4072, Australia

Corresponding author.

E-mail address: pottsr@si.edu (R. Potts).

Keywords: Adaptability; Climate variability stages; East Africa; Environmental dynamics; Null models; Variability selection 


\section{Abstract}

Interaction of orbital insolation cycles defines a predictive model of alternating phases of high- and low-climate variability for tropical East Africa over the past 5 million years. This model, which is described in terms of climate variability stages, implies repeated increases in landscape/resource instability and intervening periods of stability in East Africa. It predicts eight prolonged (>192 kyr) eras of intensified habitat instability (high variability stages) in which hominin evolutionary innovations are likely to have occurred, potentially by variability selection. The prediction that repeated shifts toward high climate variability affected paleoenvironments and evolution is tested in three ways. In the first test, deep-sea records of northeast African terrigenous dust flux (Sites 721/722) and eastern Mediterranean sapropels (Site 967A) show increased and decreased variability in concert with predicted shifts in climate variability. These regional measurements of climate dynamics are complemented by stratigraphic observations in five basins with lengthy stratigraphic and paleoenvironmental records: the mid-Pleistocene Olorgesailie Basin, the Plio-Pleistocene Turkana and Olduvai Basins, and the Pliocene Tugen Hills sequence and Hadar Basin — all of which show that highly variable landscapes inhabited by hominin populations were indeed concentrated in predicted stages of prolonged high climate variability. Second, stringent null-model tests demonstrate a significant association of currently known first and last appearance datums (FADs and LADs) of the major hominin lineages, suites of technological behaviors, and dispersal events with the predicted intervals of prolonged high climate variability. Palynological study in the Nihewan Basin, China, provides a third test, which shows the occupation of highly diverse habitats in eastern Asia, consistent with the predicted increase in adaptability in dispersing Oldowan hominins. Integration of fossil, archeological, 
sedimentary, and paleolandscape evidence illustrates the potential influence of prolonged high variability on the origin and spread of critical adaptations and lineages in the evolution of Homo. The growing body of data concerning environmental dynamics supports the idea that the evolution of adaptability in response to climate and overall ecological instability represents a unifying theme in hominin evolutionary history. 


\section{Introduction}

The way in which adaptability may have evolved in the human lineage, or in any organism, is not well understood. Adaptability refers to an increase in the ecological versatility or flexibility of a population in response to the surroundings, which can improve the ability of the population's members to (1) endure change in the environment, (2) thrive in novel environments, (3) spread to new habitats, and/or (4) respond in new ways to the surroundingscharacteristics that are evident in a wide variety of organisms and distinctive of the genus Homo (e.g., Levins, 1968; Solé and Goodwin, 2000; Potts, 2002; Kirschner and Gerhart, 2005).

Although several ideas have been proposed to account for the adaptive versatility of organisms, these ideas have largely focused on bacteria, slime mold, and other simple organisms (e.g., Woods et al., 2011). The first hypothesis to invoke natural selection in response to amplified environmental dynamics, potentially leading to an increase in adaptive versatility in hominins and other complex organisms, is variability selection. This process was proposed to explain the onset of adaptations that enhance adaptive versatility in times of strong environmental variability (Potts, 1996a, b, 1998). This idea, which was originally developed to account for aspects of hominin evolution, has since been examined from the standpoint of African environmental dynamics (e.g., deMenocal, 2004; Trauth et al., 2007, 2010; Kingston, 2007; Maslin and Christensen, 2007; Donges et al., 2011; Maslin and Trauth, 2009), faunal turnover (e.g., Bobe and Behrensmeyer, 2004; Faith and Behrensmeyer, 2013), dispersal (e.g., Grove, 2014), and computational biology as means of testing the idea's feasibility (Grove, 2011a, b). 
Figure 1 illustrates the conceptual model initially proposed to represent the process of variability selection, or VS (Potts, 1996b, 1998). The "variability" in VS refers not to more variable behaviors or other phenotypes, although these could be feasible outcomes of VS, but rather to the selective agent - the variable or inconsistent properties of the environment, which result in resource uncertainty and other disruptions to environmental structure relevant to the survival and reproductive success of particular organisms. These fluctuations in the environment and resources required by a species are ultimately mediated by Earth's changing climate, which has long been considered a driver of evolutionary change (e.g., Vrba, 1985). A controversial aspect of this conceptual model is that (a) organisms with genetic variations that happen to do well in shifting regimes of seasonality and novel habitats can have lower fitness than organisms adapted to a specific existing habitat or stable adaptive plateau, but (b) ultimately gain higher fitness over evolutionary timescales as a result of multiple generations of heightened environmental variability. As a consequence, organisms may accrue a greater degree of adaptability and out-compete organisms that succeed in a narrower range of survival conditions. It has now been shown in experimental bacteria (Woods et al., 2011) and in initial studies of nematodes (Chiu et al., 2006) that organisms having significantly lower competitive fitness can succeed in a variable environment if there is a longer-term potential for further adaptation.

While the feasibility of selection as a promoter of adaptability in the face of amplified environmental variability requires further testing mathematically and experimentally, the development of refined records and models of environmental variability in which early hominins evolved is also relevant to the question of adaptability. The initial goal of this paper is thus to present a model of climate variability relevant to tropical East Africa for the past five million years. The main contribution is to define the age boundaries of predicted climate variability 
stages, which may prove useful in testing the evolutionary and geographic responses of hominins and contemporaneous organisms to repeated transitions between low and high environmental variability.

[Figure 1 here]

Three tests of this model of alternating low/high climate variability, and its relevance to hominin evolution, are examined. The first evaluates whether regional eastern African and local basin stratigraphic records support the model of alternating stages of climate variability, including predicted long-duration intervals of particularly high climate variability. The latter are hypothesized as periods when key events in hominin evolution, especially the onset of adaptable behaviors, most likely occurred. The second test uses null models to measure the statistical strength of this predicted association between hominin evolutionary events and the most prolonged phases of high climate variability. The third test examines the implications regarding geographic expansion in Homo, specifically whether the earliest known dispersal of Homo from Africa into East Asia entailed the colonization of an extensive range of habitats, indicative of adaptability, in contrast to the idea that dispersal and colonization essentially tracked the expansion of a narrow habitat range. Each of these three tests provides a different but complementary perspective on the evolution of hominin adaptability, particularly in the genus

\section{Homo.}

\section{Methods}

High/low climate variability model for tropical East Africa 
The temporal pattern of solar insolation causes differential heating of ocean and land, which leads to seasonal shifts in wind direction and strength. Insolation thus ultimately influences the length and intensity of monsoons, bringing seasonal moisture derived from the ocean, and how far moisture penetrates the continental interior. Precessional cycles of $19 \mathrm{kyr}$ and $23 \mathrm{kyr}$ are a major determinant of the insolation-driven dynamics of seasonal monsoon circulation and the tempo of wet/dry cycles, typically described as $\sim 20 \mathrm{kyr}$ in duration. Eccentricity, which results from change in Earth's orbital shape around the sun on cycles of $~ 100$ kyr and $\sim 13 \mathrm{kyr}$, interacts with orbital precession in a manner that amplifies and dampens seasonal monsoon dynamics and the long-term intensity of wet/dry precessional cycles in the tropics. During periods of high orbital eccentricity, the long-term variability in rainfall driven by precession becomes amplified. In short, the timing and intensity of tropical solar insolation and ultimately precipitation is determined by orbital precession modulated by eccentricity (Kutzbach, 1981; Pokras and Mix, 1987; Ruddiman, 2001).

The interaction of the four cycles (two precessional, two eccentricity) results in a predictive framework of alternating high- and low-amplitude climate oscillations driven by this long-term variability in the timing and intensity of seasonal rainfall (Ruddiman, 2001; deMenocal, 2004, 2011). The boundaries between high and low variability phases are determined by orbital eccentricity according to a standard of what constitutes low variability. Here and in Potts (2013), low climate variability relevant to tropical East Africa is predicted to have occurred when eccentricity $(\varepsilon)$ was $\leq 1$ standard deviation below mean $\varepsilon$ for the past 5 million years, or $\varepsilon \leq 0.0144$. This value is modified from previous publications (Potts, 2012, 2013) based on the recent calculations of eccentricity of La2010 (Laskar et al., 2011: 
Potts and Faith: High/low climate variability

http://www.imcce.fr/Equipes/ASD/insola/earth/La2010/La2010a_ecc3L.dat). Observations by deMenocal (2004), Deino et al. (2006b), Kingston et al. (2007), Trauth et al. (2007, 2010), Maslin and Christensen (2007), Maslin and Trauth (2009), and Campisano and Feibel (2007), among other researchers, support the occurrence of relatively stable moisture-aridity levels during the low eccentricity phases and highly variable climate associated with intervening high eccentricity values.

\section{East-northeast African regional climate variability}

The framework of high and low climate variability developed here is tested using two types of long-term environmental records: (1) regional climate indicators as measured in deepsea cores, and (2) more localized terrestrial records in hominin-occupied basins (preserving evidence of hominin fossils and/or archeological remains) that have previously been studied from the standpoint of environmental dynamics.

With regard to regional records, eolian dust accumulated off the northeast coast of Africa is preserved in deep-sea drill cores in the Arabian Sea and Gulf of Aden. The combined record derived from Ocean Drilling Program Site 721/722 in the western Arabian Sea has been especially well studied; it is age-calibrated for the past 5 million years, and the data are available for analysis (deMenocal, 1995, 2004; pers. comm.; deMenocal and Bloemendal, 1995). As discussed by deMenocal (1995, 2004; deMenocal and Bloemendal, 1995), strongly seasonal rainfall stimulates the production and transport of continental eolian dust to the northeast Indian Ocean from northeast African and Arabian sources, especially during the summer monsoon winds. While the Sahel and Sahara are the most prolific sources of atmospheric dust, the strong 
rainfall seasonality of East Africa relates to sea surface temperature variation and monsoonal winds that circulate from the Indian Ocean through East Africa and off the Horn of Africa to the Gulf of Aden and Arabian Sea (deMenocal, 2004). The topographic complexity of the East African Rift System and Ethiopian highlands does not lead to a simple translation from eolian dust capture in northwest Indian Ocean to East African climate. Nonetheless, the percentage terrigenous dust measured in Arabian Sea deep-sea cores is controlled by a combination of monsoon rainfall variability and wind circulation direction and strength across tropical and subtropical East Africa. The value of the eolian dust dataset from drilling Site 721/722 arises from the 1.5-kyr resolution of terrigenous percent measurements for the entire 5-Myr interval examined here (deMenocal, 1995; deMenocal and Bloemendal, 1995).

Eastern Mediterranean sapropels comprise a second type of regional climate record relevant to this study. Sapropels are dark organic-rich layers that alternate with beige-colored strata and form thick sequences in the Mediterranean that mirror precessional cycles (e.g., Rossignol-Strick, 1983; Lourens et al., 1996; Hilgen et al., 1999; Emeis et al., 2000). In periods of intensified summer monsoon during the precessional cycle, rainfall reaches deeper into the African continent, and the resulting greater runoff leads to Nile flooding. The flushing of fresh, nutrient-rich water into the Mediterranean creates an intensified gradient from fresh surface water to anoxic bottom water, during which organic productivity at the surface accumulates as dark muds on the sea floor bottom. The color of stratigraphic sequences that contain sapropels, as measured by spectral reflectance (Sakamoto et al., 1998), is thus a measure of freshwater input draining the northeast quadrant of the African continent, related to variation in tropical monsoon intensity and thus wet-dry climate variability. 
The detailed spectral reflectance data obtained from Eastern Mediterranean ODP Site 967, at a temporal resolution of $\sim 1 \mathrm{kyr}$, is used here to test the predictive framework of alternating high and low climate variability for tropical East Africa. The Site 967A sapropel reflectance record extends back to 4.4 Ma. As with all climate proxies, multiple factors contributed to the measured climate indicator; in this case, several intersecting factors combine to elicit the formation of sapropels and their dark coloration. Climate variability in tropical East Africa is a dominant factor. However, sapropel color was also influenced by in situ variables such as Mediterranean surface-to-bottom oxygen gradients, the productivity of organic-rich remains at the surface, and ventilation/oxidation of these remains as they settled and accumulated on the seafloor (Sachs and Repeta, 1999; deMenocal, 2004). Analysis of elemental composition for Site 967 shows, nonetheless, that sapropels formed exclusively during times of strong Nile discharge associated with African humid periods; intervals of increased organic productivity at Site 967 lasted 8-12 kyr within the $20-k y r$ duration of precessional cycles, implying that the wet periods of precessional cycles persisted this long relative to the more arid periods in the tropical east-northeast quadrant of the African continent (Wehausen and Brumsack, 1998, 1999).

For the eolian dust record from Site 721/722 and the sapropel record from Site 967A, change in the standard deviation of dust flux and sapropel reflectance is examined to test whether the expectation of increased and decreased variation matches the predicted pattern of alternating phases of higher and lower climate variability over time. Standard deviation is calculated using all measurements within each high and low climate variability stage.

\section{Terrestrial basin environmental dynamics}


Tests of how well the regional dust and sapropel records correspond with predicted stages of climate variability are complemented by outcrop records of lake oscillation, lake-land transitions, and landscape remodeling events in sedimentary basins where evidence of early hominins is preserved. For particular time intervals, continuous (or nearly so) environmental dynamics have been developed in sufficient detail in five East African sedimentary basins to test predicted transitions between low and high climate variability: Hadar Formation (3.4-3.0 Ma); Chemeron Formation, Tugen Hills (2.7-2.5 Ma); Koobi Fora Formation, East Turkana (1.9-1.7 Ma); Olduvai Bed I (1.9-1.7 Ma); and the Olorgesailie Formation (1.1-0.9 Ma; Potts et al., 1999; Deino et al., 2006b; Ashley; 2007; Campisano and Feibel, 2007; Lepre et al., 2007; Quinn et al., 2007; Dupont-Nivet et al., 2008; Owen et al., 2008; Potts, 2013).

Lake level fluctuations and lake-land transitions, along with variation in sediment accumulation rates and stable isotope stratigraphies, have proved useful in reconstructing environmental dynamics from these outcrop records, as described in the preceding references. Lake variability is typically reconstructed based on the presence of lacustrine facies and diatom indicators of lake depth and chemistry. Land variability is typically assessed based on the extent of aggradational fluvial and floodplain deposits, paleosols (indicative of temporary stability in floodplain deposition), and stable isotopic and geochemical indicators of habitat.

The investigation of these five African stratigraphic records tests whether four of the lengthiest intervals of high climate variability, as predicted by the high/low variability model, were, in fact, recorded in more localized areas where hominins lived. Whether or not such intervals expanded the adaptability of early hominins can be tested by study of the environments of major geographic dispersal events. In this paper, we focus on the oldest known dispersal of Homo from Africa to East Asia, 1.9 to 1.7 Ma, and examine whether the East Asian area of 
colonization was characterized by a fairly constrained habitat range, as might occur if dispersing hominins had tracked the expansion of savanna grassland or another particular type of environment (Dennell and Roebrooks, 2005; Dennell, 2010), or possibly a broader range of habitats as would be predicted if African dispersers had attained a certain degree of adaptability in a period of magnified climate variability.

For this part of the study, we rely on a detailed pollen study of the Nihewan Basin, where archeological evidence of hominin toolmakers is well established between 1.66 and $1.34 \mathrm{Ma}$ (Zhu et al., 2004). Nihewan paleoenvironmental evidence is complemented by pollen and sedimentary grain size analyses for the Loess Plateau after 2.6 Ma (Wu et al., 2007).

\section{Null models}

Although most hypotheses linking climate change to human evolution require synchrony between climatic and evolutionary change, establishing a causal relationship between them requires, among other things, close scrutiny of the apparent synchrony of events (Behrensmeyer, 2006). This includes assessing the statistical meaning of any apparent correspondence. Because most relevant climate records, including those examined here, are dynamic and document repeated phases of change, it is likely that synchrony between climatic and evolutionary change could be observed by chance alone. In this study, we implement a series of null models to quantitatively evaluate the association between climatic and evolutionary change.

Null models are commonly used in ecology to distinguish meaningful patterns from random noise (Gotelli and Graves, 1996; Manly, 1997; Gotelli, 2001). Following Gotelli and Graves (1996), a null model is a pattern-generating model based on the randomization of data or 
randomized sampling from known or specified distributions, the purpose of which is to generate patterns that are expected to occur in the absence of a particular causal mechanism (e.g., a causeeffect relationship between climate and evolution). The null model thus represents a null hypothesis against which the empirical data are compared. Correspondence between the empirical data and the null model implies that the null hypothesis cannot be rejected, in which case there is little need to invoke a special causal mechanism to explain observed patterns. Conversely, a difference between the empirical observations and the null model indicates that the null hypothesis should be rejected, implying that the empirical data have been structured by some underlying causal mechanism.

We use the null model approach to evaluate the correspondence between prolonged phases of climate variability and key events in hominin evolution over the last $5 \mathrm{Ma}$. These include the currently known first and last appearances of hominin species in East Africa, in addition to major phases of technological innovation (the emergence of novel Paleolithic industries) and hominin dispersal events out of Africa. The null models used here are simple randomization procedures, whereby the chronology of evolutionary events is randomized with respect to phases of climate variability, generating patterns that would be expected in the absence of an association between the two.

Specifically, our null models randomize the current chronology of evolutionary events through the last 5 Myr. For each of 5,000 iterations, the number of evolutionary events (e.g., FADs of hominin species) overlapping with a prolonged high climate variability (CV) stage is tallied. This procedure generates a frequency distribution indicating the probability of randomly observing correspondence between evolutionary events and prolonged high CV stages assuming no underlying relationship between them. If the empirically observed patterns deviate from the 
null models (i.e., if they are improbable outcomes) and other potential biases can be accounted for, it follows that there may be a causal relationship between climate variability and evolutionary change.

Rather than treating evolutionary events as discrete points in time, the null models used here recognize that the relevant archeological and fossil sites are often broadly constrained by age ranges on the order of $10^{3}$ to $10^{5}$ years. We consider an evolutionary event to correspond to a prolonged high $\mathrm{CV}$ stage when its age range overlaps with such a phase. For example, the emergence of Homo at 2.80 to $2.75 \mathrm{Ma}$ (Villmoare et al., 2015) corresponds to prolonged high CV stage H18 (2.467 to $2.795 \mathrm{Ma}$; see Table 1). Note that this protocol, which takes into account potentially broad age constraints, raises the chances of randomly observing a correspondence between an evolutionary event and a prolonged high CV stage, as poorly constrained events associated with broad age ranges are more likely to randomly overlap with a high CV stage. This approach thus does not bias our analysis because it implies that the null model will show a reasonably large number of overlaps by chance alone; in other words, it will be harder to reject the null hypothesis, and the empirical correspondence must be very striking to obtain significant results. In short, the null models allow us to evaluate the degree to which associations between climate variability and the evidence of evolutionary events can be explained by random chance. The null model analyses are carried out using the R Statistical Package (R Core Development Team, 2013).

[Table 1 here]

\section{Results}


Potts and Faith: High/low climate variability

Stages of high and low climate variability

Table 1 (columns A through F) defines the predicted stages of high and low climate variability for tropical Africa for the past five million years. The bottom and top age for each stage corresponds to the point in the sequence of eccentricity calculations that passes above or below 0.0144 , which conveys the suggested threshold criterion in the precessional index (i.e., the modulation of precession by eccentricity) dividing high and low variability.

The stages have been numbered from youngest to oldest, starting with H1 and L1. The predictive model captures the alternation between high and low climate variability, a pattern that serves as a hypothesis to describe the setting of hominin evolution in Africa. This model of repeated switching between low and high variability differs from marine isotopic stages and the progressive increase in amplitude of climate variability as measured by $\delta^{18} \mathrm{O}$ in benthic foraminifera in deep-sea cores. The alternating 'packets' of high and low variability have previously been noted by deMenocal $(2004,2011)$ as characteristic of African climate variability. Specific phases of high climate variability have been the focus of previous analyses (e.g., Trauth et al., 2005, 2007, 2010; Deino et al., 2006b; Ashley, 2007; Campisano and Feibel, 2007; Kingston et al., 2007; Maslin and Christensen, 2007; Donges et al., 2011). These authors have noted that marked expansion and fluctuation of lakes occurred during high eccentricity phases, and that three such phases mainly marked by lake expansion ('humid phases') had a critical influence on human evolution (e.g., Trauth et al., 2005; Maslin and Christensen, 2007; Donges et al., 2011). The high/low climate variability (CV) stages presented here extend upon this prior work by illustrating that high variability and relatively stable climate switched back and forth throughout the Pliocene and Pleistocene (see also deMenocal, 2004). 
The model predicts 32 high CV stages of durations ranging from $19 \mathrm{kyr}(\mathrm{H} 3)$ to $328 \mathrm{kyr}$ (H18 and H31) over the past 5 million years. In this study, we emphasize the eight most protracted of these phases (i.e., the top 25\%), each of which is $>192 \mathrm{kyr}$ long. These are CV Stages H2, H9, H14, H17, H18, H19, H30, and H31, and they are examined in further detail below in terms of their potential influence on past environmental change and hominin evolution and adaptability.

[Figure 2 here]

\section{Stratigraphic records associated with high climate variability}

The model of alternating phases of high- and low- climate variability closely predicts variation in the records of eolian dust flux from the western Arabian Sea (ODP Site 721/722) and, to a lesser extent, sapropel reflectance from the eastern Mediterranean Sea (ODP Site 967A; Table 1, columns G to L). The eolian dust record spans 60 transitions across the predicted variability model for the past 5 million years; the change in standard deviation matches 53 of those predicted increases or decreases in variability (88\%). The sapropel reflectance data span 59 high/low or low/high transitions over the past 4.4 million years, with 37 matches $(63 \%)$.

The dust record shows the rise in standard deviation that is predicted for each of the eight prolonged (>192 kyr) high climate variability phases relative to the preceding low variability phase. The slightly shorter sapropel reflectance record from Site 967A covers seven prolonged high variability phases, and six of these show substantial increases in standard deviation from the prior low phase. The one that does not (CV Stage H18: 2.795 to 2.467 Ma) arises from the 
persistence of a large standard deviation across the preceding low variability stage, such that the sequence of Stages H19 - L18 - H18 (spanning 3.197 to 2.467 Ma) continuously registers high variability in sapropel reflectance. In brief, variation measured in both the empirical dust and sapropel records independently supports the validity of the protracted phases of high-amplitude climate variability predicted by the model.

Across climate variability stages overall, there is a significant correlation between mean eccentricity and the standard deviation of both dust flux $(r=0.611, p<0.001)$ and sapropel reflectance $(r=0.283, p=0.028)$. To quantify how well changes in the variability of the dust and sapropel records correspond to predicted transitions in climate variability, Figure 2 illustrates the relationship between the difference in mean eccentricity from one climate variability stage to the next and the corresponding change in the standard deviations of dust flux and sapropel reflectance (i.e., positive values indicate increased variability and vice versa). These relationships are highly significant for both the dust $(\mathrm{r}=0.785, \mathrm{p}<0.001)$ and sapropel records $(\mathrm{r}=0.517, \mathrm{p}<0.001)$. It follows that changes in the variability of these records conform to the expected transitions in climate variability.

Observations of long stratigraphic records in hominin-inhabited basins of East Africa further indicate that these longest phases of strong climate instability were registered in places occupied by early hominins and associated biotas. Results from Hadar, Tugen Hills, Turkana, Olduvai, and Olorgesailie are summarized below:

Stage H19-Hadar: 3.2-3.0 Ma 
At Hadar, Ethiopia, the record of Australopithecus afarensis covers the period from $~ 3.4$ to 3.0 Ma, the latter half of which coincided with the predicted high variability Stage H19 (3.197 to 2.905 Ma). Campisano and Feibel (2007) were the first to point out that the interval recorded at Hadar from roughly 3.2-3.0 Ma coincided with a time of high-amplitude climate variability related to eccentricity-modulated precession. They note a distinct change in Hadar sediments and paleoenvironments at $\sim 3.15$ Ma consistent with strong variability. Because sediment accumulation is also directly tied to subsidence and local tectonics, it highlights the caution required in using the model developed here in interpreting sedimentary and other variables that may be only indirectly related to climate. Nonetheless, Campisano and Feibel (2007) and Dupont-Nivet et al. (2008) emphasize that the Hadar record shows distinct shifts in variability, and that ecological turnover in the fauna (rise in arid-adapted taxa; Reed, 2008) and hominin morphology (increase in mandibular and concomitant body size; Lockwood et al., 2000) coincided with high variability Stage H19. The last appearance of A. afarensis in the Hadar sequence is in sediments dated to between 3.03 and 2.97 Ma (Brown et al., 2013), after which there is a major erosional unconformity (Campisano and Feibel, 2007), and isolated teeth that may belong to the species are found in the portions of Shungura Fm Member B dated to between 2.97 and 2.85 Ma (Grine et al., 2006; Brown et al., 2013). Whichever date is accepted, the last known appearance of $A$. afarensis overlaps with Stage H19..

Stage H18 - Tugen Hills, Chemeron Formation: 2.7-2.5 Ma 
A distinctive characteristic of the Chemeron Fm is the recurrence of thick lake diatomites that alternate with subaerial sediments dated from 2.7 to $2.55 \mathrm{Ma}$ (Deino et al., 2006b; Kingston et al., 2007). Five diatomites have been identified, and these correspond to the calculated ages of peak insolation affecting the northern African monsoon. These deep lake phases and intervening drops in lake level reflect strong variability at precessional periodicities related to high eccentricity, which defines CV Stage H18 in the alternating model presented in this paper. The greatest variability, as indicated by recurrent deep lake sediments interbedded with fluvial and alluvial fan sediment, occurs in the middle of the predicted high variability interval. Three sites that yield hominin fossil fragments are known within this stratigraphic sequence. Although the idea had been discussed since the 1980s (Vrba, 1988, 1995; deMenocal, 1995; Potts, 1996a), the analysis of the Chemeron diatomite sequence provided the first direct geochronological support for orbital forcing of East African climate dynamics (Deino et al., 2006b). Trauth et al. (2005, 2007) further proposed that the high variability phase between 2.7 and $2.5 \mathrm{Ma}$ was expressed over much of East Africa.

Stage H14 - Turkana, Koobi Fora Formation; and Olduvai Beds I-Lower II: 1.9-1.7 Ma

Four distinct hominin morphological groups are represented in the Turkana Basin during the time of CV Stage H14; these are typically considered distinct lineages associated with the taxonomic names $P$. boisei, $H$. rudolfensis, $H$. habilis, and H. erectus (e.g., Wood, 1991; Antón et al., 2014). Sedimentary facies analysis offers evidence of heightened environmental variability expressed by marked lake level fluctuation in this stratigraphic interval (KBS Member) of the Koobi Fora Fm, consistent with strong wet-dry variability predicted for H14 (Lepre et al., 2007). 
In the earlier Upper Burgi Member (2.09 to $1.87 \mathrm{Ma}$ ), sedimentary, geochronological, and strontium isotopic analyses by Joordens et al. $(2011,2013)$ show that, while precessional climate cycles are evident, permanent water and moist wooded habitats were consistent features of the Turkana Basin up to $1.87 \mathrm{Ma}$, coinciding with the onset of CV Stage H14. Within this earlier interval, the range of variation in strontium isotopic values is approximately $3 \mathrm{x}$ greater in $\mathrm{H} 15$ than in L16 (Joordens et al., 2013: Fig. 4). A long-term reduction in Turkana lake size characterized Stage H14 in the period from 1.9 to 1.7 Ma (Feibel et al., 1991), and stable carbon isotopic values of pedogenic carbonates document an increase in vegetational variability over time and space in the period from $\sim 1.87$ to $\sim 1.7 \mathrm{Ma}$ (Quinn et al., 2007). Faunal turnover reaches a peak in the Turkana Basin during this interval (Behrensmeyer et al., 1997), coincident with an overall increase in arid-adapted fauna in other areas of East Africa (Reed, 1997; Bobe, 2006).

The same time interval is recorded in Beds I and Lower II of the Olduvai sequence, in which changes between moist and arid have long been recognized (e.g., Hay, 1976; Jaeger, 1976; Bonnefille 1984). According to Ashley (2007), five main episodes of lake expansion and contraction are related to precessional cycling during a phase of high eccentricity, as reflected in the high/low variability model. That same study further deduces that rainfall in any given wetdry precessional cycle would have been approximately one-third higher during this period. Geochronological analysis by Deino (2012) provides precise age control for this orbitallycontrolled variability: the most marked lake expansion occurred at $1.85 \mathrm{Ma}$, followed by repeated regressions and lake expansions to the top of Bed I (1.80 Ma). The times of high lake levels correspond to peak insolation values pertaining to northern African monsoon circulation, which would have been responsible for heightened moisture accumulation in East Africa (Deino 2012). The top of Bed I was characterized by marked aridity, followed by continuing lake 
expansions and contractions through Lower Bed II up to 1.74-1.70 Ma (Ashley, 2007). As Deino (2012) has determined, the exact timing of lake expansions is connected to specific insolation peaks; the hypothesized linkage between northern African monsoons and East Africa wet-dry intensity is consistent with eccentricity-modulated precession as the basis for the predictive model advanced in this paper.

In brief, the Olduvai lake level record between 1.85 and 1.70 is indicative of pronounced moist-arid cycles coinciding with high eccentricity-modulated precession, which defines CV Stage H14. This stage corresponds to one of three African humid periods identified by Trauth et al. (2005). The record of lake level fluctuations and increase in arid-adapted fauna suggests that this period is better characterized as a time of intensified climate variability.

Stage H9-Olorgesailie Formation: 1.1-0.9 Ma

Environmental dynamics have also been a focus of study in the Olorgesailie Fm of the southern Kenya Rift, which preserves a rich sequence of Acheulean tool assemblages and the current last appearance datum (0.97 to 0.90 Ma) of H. erectus in East Africa (Potts et al., 2004). The Olorgesailie Fm, dated $\sim 1.2$ to $0.5 \mathrm{Ma}$, registers a dynamic oscillation of lake- and landdominated environments in the Olorgesailie Basin (Deino and Potts, 1990; Behrensmeyer et al., 2002). Stratigraphic analysis of wetland and lake habitats and of terrestrial settings associated with fluvial, floodplain, and soil-forming environments shows that a particularly volatile era of environmental fluctuation occurred between 1.1 and $0.9 \mathrm{Ma}$ (Owen et al., 2008), in the interval represented by CV Stage H9. The high resolution sedimentary record of upper Member 1 through Member 5 of the Olorgesailie Fm, spanning 18 kyr, especially illustrates the large 
swings between moist and arid (deep lake-dominated and $\mathrm{C}_{4}$ grass-dominated landscapes) near the mid-point of Stage H9 (Potts et al., 1999). This marked variability in landscape and lake levels is in line with not only orbital forcing but also millennial-scale climate dynamics.

Potts and A.K. Behrensmeyer have conducted a study of landscape change at a variety of spatial scales in the Olorgesailie Basin. The first order of resolution focuses on major land-lake reorganizations affecting variables such as water availability and substrate characteristics. These first-order landscape changes were the result of climate and tectonic and eruptive activity. They entailed, for example, shifts between lake- and fluvial-dominated habitats; between aggrading, eroding, and soil-forming environments; and disturbances caused by deposition of thick tephra ( $\geq 1 \mathrm{~m}$; Potts, 2001). Although climate is not the only determinant of these environmental reorganizations, the expectation for the predicted high variability of CV Stage H9 is that a substantially greater portion of landscape remodeling events would occur in this 200-kyr interval relative to the entire $700 \mathrm{kyr}$ of the Olorgesailie Fm. Based on extensive data currently available (Potts, 2013), 70\% ( $n=21)$ of basinwide landscape shifts $(n=30)$, including large-scale lake/land oscillations, occurred in the H9 interval of predicted high-climate variability (1.1-0.9 Ma), compared to $30 \%$ in the remaining 500,000 years of the Olorgesailie Formation.

\section{[Table 2 here, Figure 3 here]}

\section{Hominin evolutionary events}

Our second test of the hypothesis that climate variability influenced evolution is provided by examining the association between the eight prolonged phases of heightened climate 
variability (Table 1) and the chronology of major events in hominin evolutionary history (Table 2). These major events include the currently known first and last appearance datums (FADs and LADs) of hominin taxa in East Africa, the emergence of new Paleolithic industries (Lomekwian, Oldowan, Acheulean, Middle Stone Age, and Late Stone Age), and the dates for hominin dispersal events out of Africa. While speciation and behavioral adaptations reflect different aspects of evolutionary history, they can be subject to the same environmental dynamics and selection pressures. Specifically, the VS hypothesis predicts that heightened environmental variability can elicit not only change in behavioral capacities expressed as cultural/technological innovations but also habitat fragmentation and reorganization, which in turn can lead to population vicariance and allopatry, essential precursors to extinction and speciation (Vrba, 1985). However, because lineage turnover and cultural innovations are susceptible to different combinations of factors, we treat them separately in our null models.

Our analysis focuses on taxa relatively well represented in the fossil record with reasonably tight age constraints. Kenyanthropus platyops (Leakey et al., 2001) is excluded from Table 2 and from the following analyses because it refers to a poorly known monospecific genus of unknown temporal range. Other taxa with poorly constrained temporal ranges (Australopithecus garhi [Asfaw et al., 1999], Au. deyiremeda [Haile-Selassie et al., 2015], and Ardipithecus ramidus [White et al., 2009]) are likewise excluded from this analysis because their identical or nearly identical FADs and LADs imply that one or both values do not accurately estimate the earliest or latest lineage age. Although some analysts use the name Homo rhodesiensis for an African middle Pleistocene predecessor of $H$. sapiens, the dearth of African hominin fossils dated between $1 \mathrm{Ma}$ and $600 \mathrm{ka}$ (Potts et al., 2004), along with poor age 
constraints on fossils from sites such as Elandsfontein and Ndutu that could be assigned to this species prior to the Bodo cranium at $\sim 600 \mathrm{ka}$, leads us to set this taxon aside in our analyses.

With the caveat that the dates for FADs and LADs are constantly subject to revision as samples increase and deposits are re-dated, we observe a strong correspondence between the currently established FADs and LADs of the remaining taxa with prolonged phases of high climate variability (8 of 9 FADs and 4 of 7 LADs). In addition, near perfect correspondence is observed for the major technological and biogeographic events (6 of 7 events; Table 2).

Because the eight phases of high variability account for a combined 2.137 Ma over the last $5 \mathrm{Ma}(42.7 \%$ of the geological record), there is a reasonable probability that synchrony could be observed by chance alone. Here we use null models to assess the extent to which the empirical observations can be explained by random chance. The first null model estimates the probability of randomly observing correspondence of an evolutionary event with any of the eight phases of high climate variability (i.e., it assumes no underlying relationship between the two). For each of 5,000 iterations, the temporal windows bracketing evolutionary events are randomized through the past $5 \mathrm{Myr}$, and the number of events overlapping with a high variability climate phase in each iteration is tallied. Note that these temporal windows are variable depending on the age constraints associated with a species FAD/LAD or technological/dispersal event (Table 2).

A schematic illustration of our null model is presented in Figure 3, which shows the empirically observed FADs of East African hominin species relative to prolonged high CV stages and a single iteration of the null model, whereby the temporal windows bracketing an evolutionary event (e.g., a $0.05 \mathrm{Myr}$ window in the case of earliest Homo) are randomized through the past 5 Myr. This iteration shows 5 of 9 events randomly overlapping with a prolonged high $\mathrm{CV}$ stage, compared to an empirical observation of 8 overlaps. By repeating the 
randomization procedure 5,000 times, it is possible to assess whether the empirical observation is a probable outcome (i.e., indistinguishable from random) or an improbable outcome (i.e., nonrandom).

Figure 4 illustrates the null model results in the form of histograms indicating the randomized number of evolutionary events that overlap with a prolonged high variability phase; arrows indicate the empirical observation (Table 2). With respect to hominin speciation events (FADs), the most common outcome is for 5 of the 9 FADs to overlap with a prolonged phase of high climate variability (1,264 of 5,000 iterations). The probability of observing 8 or more FADs overlapping with a phase of high climate variability by chance alone is unlikely (119 of 5,000 iterations: one-tailed $\mathrm{p}=0.024)$, implying that the empirically observed FADs are not randomly distributed with respect to phases of high climate variability (i.e., a causal relationship is possible). There is little case to be made for a causal relationship involving the LADs, however, as the null model shows that the empirically observed pattern is the most common randomized outcome; the probability of randomly observing correspondence across $\geq 4$ LADs is high $(3,460$ of 5,000 iterations: one-tailed $\mathrm{p}=0.692$ ). Lastly, applying the same approach to the technological and biogeographic milestones indicates that correspondence across 6 of 7 events is very unlikely (207 of 5,000 iterations: one-tailed $\mathrm{p}=0.041$ ).

These analyses are consistent with the hypothesis that evolutionary change was focused in prolonged phases of heightened climatic variability.

[Figure 4 here] 
The temporal distribution of fossil and archeological sites

A factor that could yield a biased association of FADs and LADs with the eight prolonged intervals of high climate variability is if hominin fossils and archeological finds, on which FADs and LADs are based, are preferentially preserved in these intervals relative to other climate variability stages. This bias could result, for example, if the prolonged high CV stages were characterized by faster sedimentation rates, leading to better preservation of hominin evidence. Are more sites and fossils found within these longest periods of climate instability?

A compilation of East African hominin fossil and archeological sites for the past 3.5 million years by Patterson et al. (2013) indicates that there is no such bias. The Patterson et al. compilation includes 51 fossiliferous Pliocene and Pleistocene assemblages (members, beds, and individual sites) that encompass CV Stages L22 through H1. Of these assemblages, 36 are associated with age ranges that allow us to calculate the approximate temporal duration represented in a given fossil assemblage. (Age ranges for Omo Members B and K were added following the stratigraphy in Bobe and Behrensmeyer [2004], and the Kada Hadar Member of the Hadar Formation was excluded because it duplicates the entry for the Hadar Formation.) The total amount of time represented in the prolonged high CV Stages is 5.520 Myr compared to 6.197 Myr in other CV Stages. This equates to $47 \%$ of the time in a prolonged high CV stage, which corresponds almost exactly to the $46 \%$ of the geological record (1.61 Myr) represented by prolonged high CV stages over the last 3.5 Myr. This suggests that the East African PlioPleistocene fossil record does not preferentially sample prolonged high CV stages (i.e., it is random with respect to climate variability). 
Further evidence against preservation biases that could favor an anomalous link between key evolutionary events and prolonged high CV stages is provided by abundant, well-calibrated hominin records that have been studied in fine stratigraphic detail, such as the fossil-rich Hadar Formation and the archeologically-rich Olorgesailie Formation. At Hadar, prolonged CV Stage H19 begins at the base of the Kada Hadar Tuff, dated 3.20 Ma, and ends at the top of the Hadar Fm ( 2.95 Ma; Walter, 1994; Campisano, 2007; Campisano and Feibel, 2008). While Stage H19 is thus represented by $\sim 250 \mathrm{kyr}$ in the Hadar Fm, all other CV stages encompass $\sim 220 \mathrm{kyr}(\sim 3.4$ to $3.2 \mathrm{Ma}$ ). Of 114 specimens or individuals (comprising multiple skeletal elements) of Australopithecus afarensis discovered in the Hadar Fm in 1973-1977, 1990-1994, and 19992001 (Johanson et al., 1982; Kimbel et al., 2004), only 24 are dated to the prolonged high H19 ( 10 occurrences/ $100 \mathrm{kyr})$ whereas 90 fossil occurrences to all other CV stages ( 41 occurrences/100 kyrs). Fossils attributable to a single individual, e.g., AL 444, are counted as $n=$ 1, and an MNI of 17 individuals from Site 333 in DD-2 of the Denen Dora Member is included in the 'all other' total (Harmon et al., 2003; Behrensmeyer, 2008). Based on a composite section of the Hadar Fm (Campisano and Feibel, 2008), prolonged CV Stage H19 is represented by 60 $\mathrm{m}$ vertical thickness and $\sim 250 \mathrm{kyr}$ of time $(=0.24 \mathrm{~m} / \mathrm{kyr})$, while all other $\mathrm{CV}$ stages are represented by $\sim 90 \mathrm{~m}$ of sediment and $\sim 220 \mathrm{kyr}$ of time $(=0.41 \mathrm{~m} / \mathrm{kyr})$. Thus, the prolonged high variability stage preserved in the Hadar Fm exhibits a lower sedimentation rate than other intervals, and hominin fossil discoveries are roughly 4x fewer during CV Stage H19 than in all other CV stages.

The well-studied stratigraphic sequence at Olorgesailie provides a parallel test with regard to archeological site preservation. Based on the past three decades of excavation and survey (Potts et al., 1999; Potts, 2001, 2013; Behrensmeyer, 2002), 29 archeological levels have 
been located in the Olorgesailie Fm, spanning 700,000 years. Only five such levels are situated in prolonged CV Stage H9 (= 2.5 levels/100 kyr), whereas 24 levels occur in all other CV stages combined (= 4.8 levels/100 kyr). Furthermore, Olorgesailie, Tugen Hills, Olduvai, and Turkana were all prominent lake basins that exhibited periods dominated by lacustrine deposits (thick diatomites or lacustrine clays) in which terrestrial records of hominin fossils/sites are lacking. These lake-dominated periods are a prominent characteristic of many of the prolonged high CV stages, defined by high orbital eccentricity (e.g., Trauth et al., 2005, 2007; Deino et al., 2006a Kingston et al., 2007; Owen et al., 2008; Deino, 2012; Potts, 2013). This prominence of lake sedimentation thus appears to create a bias against the preservation of hominin evidence in prolonged high variability intervals, and thus would tend to decrease the concentration of FADs and LADs in prolonged intervals of strong climate variability due to random chance.

Thus sedimentary rates and the distribution of hominin fossils and archeological sites do not explain the strong correlations we have found in the null model analyses. Evidence is lacking for better preservation or a greater likelihood of fossil and archeological sites in the prolonged high CV stages. Where sampling biases are observed, they indicate the opposite, in which case our null models are potentially overly conservative. In other words, they might overestimate the probability of an evolutionary event taking place within a high CV stage, resulting in p-values that are too high. For these reasons, the marked association of key lineage FADs and behavioral/dispersal milestones with long-duration high variability is especially unlikely to be attributable to random chance alone. These observations are consistent with, and strongly imply, a cause-effect relationship between climatic variability and evolutionary change.

FADs and evolutionary lag effects 
FADs, which are pieces of dated fossil or archeological evidence, refer to the first documented records of particular evolutionary events. Any such datum helps constrain, at least roughly, the age of the evolutionary event in question. We recognize that empirically observed FADs may deviate from the true age of the event in question because of insufficient sampling or gaps in the sedimentary record (e.g., Signor and Lipps, 1982; Marshall, 1990; Bobe and Leakey, 2009). However, the error in the FADs used here (Table 2) should be random with respect to climate variability. That is, there is no obvious reason why random sampling error would cause most FADs to cluster in prolonged high CV stages, especially considering the lack of bias that might contribute to preferential representation of fossils during prolonged high CV stages. Assuming that any error in FADs is random with respect to CV stages, the probability of observing such correspondence by random chance alone is represented by the p-values generated in our null models (i.e., it is unlikely). Thus, it is difficult to explain the empirical correspondence between FADs and prolonged high CV stages by random sampling error in the chronology of evolutionary events.

A complicating factor in all analyses of environment and evolution — in fact, in any study regarding the causes of evolutionary change — is evolutionary lag, the likely time delay between the causes of an evolutionary innovation or transition, the event itself (e.g., the origin of the innovation), and the manifestation of the event in the geological record. Previous studies (e.g., Foley, 1994; Vrba, 1995; Dongas et al., 2011) recognize this complication, yet do not resolve the issue. Although we are also unable to provide meaningful estimates concerning the potential duration of evolutionary lag, we assume that the protracted climate variability stages — no less than 192,000 years long-represent time intervals potentially long enough to encompass lags 
between the onset and the spread of key evolutionary innovations. Others have observed that both extinction (e.g., Faith and Behrensmeyer, 2013; Faith, 2014) and speciation (e.g., van Dam et al., 2006) can be very tightly linked to climate change — at least over geological timescalesimplying that any lag is of insufficient duration to be detected in the record or to obscure valid associations between climate dynamics and evolutionary change.

[Figure 5 here]

Climate dynamics of dispersal in early Homo

Geographic dispersal can help test the idea that environmental instability can be an evolutionary driver of adaptability. If the intensification of climate variability can lead to conditions of natural selection favoring an increase in adaptability, the effect should be that geographic dispersals will (1) correlate with periods of magnified environmental fluctuation in the source region, and (2) result in the colonization of highly-diverse novel environments. These two implications argue against an alternative idea that dispersals result as populations track the expansion of a specific type of habitat (e.g., grassland), which is considered to be the "preferred habitat" of early hominins.

Here we consider the dispersal of early Homo, often considered to be early African Homo erectus, to Eurasia. The current FAD for Homo in Eurasia is represented by fossils typically referred to as early $H$. erectus at $\sim 1.78 \mathrm{Ma}$ from Dmanisi, Georgia, with an earlier date of $\sim 1.85$ Ma represented by Oldowan stone tool assemblages also from Dmanisi (Ferring et al., 2011; Lordkipanidze et al., 2013). Therefore, the current time frame of what is sometimes called 'Out 
of Africa I'—-from 1.85 to $1.78 \mathrm{Ma}$ - coincides with the protracted phase of high climate variability in East Africa, CV Stage H14, from 1.888 to 1.695 Ma (Table 1).

The continued spread of Homo across Asia is currently reflected by fossil and archeological evidence from China and Indonesia at 1.7-1.66 Ma. The earliest date of 1.7 Ma applies to stone tools from the Yuanmou Basin, Yunnan, southern China, associated with two central incisors essentially identical in their surface features to the $\sim 1.6 \mathrm{Ma} \mathrm{H}$. erectus juvenile from Nariokotome, Turkana Basin, Kenya (Zhu et al., 2008). Multiple layers of Oldowan artifact assemblages are documented in the Nihewan Basin, Hebei, northern China, beginning 1.66 Ma from the Majuanguo site (Zhu et al., 2004). These archeological assemblages at $40^{\circ} \mathrm{N}$ latitude are of contemporaneous geological age established for fragmentary remains of Homo, typically assigned to $H$. erectus, from Sangiran and possibly Modjokerto, Java, Indonesia (Swisher et al., 1994; Antón and Swisher, 2004). (The likely stratigraphic position of the Modjokerto fossil discovery was $\sim 20 \mathrm{~m}$ above the tephra dated $\sim 1.8 \mathrm{Ma}$, and thus is younger than that age [Huffman et al., 2006]).

Figure 5 presents a detailed palynological analysis from the Majuanguo site in the Nihewan Basin based on collaborative studies (with R.P.) at Hebei Normal University by Xu Qinghai and the Institute of Geology and Geophysics in Beijing by Zhu Rixiang, Deng Chenlong, and colleagues. Pollen grains were collected from continuous lacustrine facies at Majuanguo, and their identification falls into standard taxonomic categories. A subset of the palynomorphs can then be grouped into woodland/mesic versus grassland/arid taxa. The stratigraphic positions of four archeological layers at Majuangou (Zhu et al., 2004) indicate that hominin activity corresponds to strong variation in pollen assemblage composition, indicative of a range from $\sim 60 \%$ arid-grassland taxa to nearly $100 \%$ mesic-woodland taxa. Pollen analysis of 
the central Loess Plateau similarly indicates fluctuation between $\sim 50 \%$ shrubs/herbs to $100 \%$ conifers over the interval from 1.85 to $1.5 \mathrm{Ma}$ (Wu et al., 2007). Hominin toolmakers apparently first colonized northeast Asia in the context of this sequence of diverse vegetational habitats. The near-equatorial habitats of Indonesia, at latitude $7^{\circ} \mathrm{S}$, greatly enlarged the range of East Asian environments into which Homo was able to disperse by 1.66 Ma (Antón, 2003).

Whatever complex of factors and conditions enabled the dispersal of early H. erectus across Asia, the degree of evolutionary adaptability to environmental diversity and variability in early $H$. erectus had evidently surpassed that of earlier African hominins. The emergence and spread of Oldowan technology, as part of the adaptive repertoire of early Homo, during two notably long phases of high variability — Stages H18 and H17—very likely set the stage for dispersal into new climatic and biotic zones.

\section{Discussion: hominin responses to environmental dynamics and the evolution of adaptability}

The basis for the model of alternating climate dynamics is that orbital eccentricity acts to amplify and diminish the intensity of wet-dry variation during precessional cycles. Two regional climate records — northeast African eolian dust and eastern Mediterranean sapropels_-afford two distinct tests of the alternating high/low variability model. The two datasets reflect different processes and sources of input: sapropels formed by Mediterranean Sea floor anoxia as the result of strong Nile water input, and the dust flux record by the incorporation of continental dust into Arabian Sea deposits due to a combination of African aridity and winds. The two records thus 
also reflect different aspects of wet-dry climate cycles - heightened moisture in the case of sapropels, and heightened aridity and wind strength in the case of eolian dust.

Correspondence of the two separate records with the predicted direction of change in high/low variability indicates the overall regional effect of the penetration of monsoons across East Africa, and offers evidence for the causal connection between eccentricity-modulated precession and East African climate dynamics. The temporal pattern of increased and decreased variation in each data set supports the predicted alternation of high and low climate variability, and confirms the validity of the eight longest high variability phases also predicted by the model (upper quartile of all high variability stages in terms of duration).

Equally important is the finding that climate variability patterns are registered at key hominin localities, a critical link often neglected in climate-evolution studies. Analyses of long stratigraphic records in East African sedimentary basins inhabited by early hominins confirm strong lake level and landscape variability during prolonged high variability stages.

Across the full set of lineage FADs, LADs, and events shown in Table 2, null model tests show a statistically significant association between the eight longest phases of high variability, on the one hand, and species FADs and technological/dispersal events, on the other, but not for species LADs. We further show that sedimentary rates and any potential biases of fossil and archeological site preservation in relation to climate variability do not favor a priori the occurrence of evolutionary FADs in the prolonged high CV stages. The significant correlation between prolonged high CV stages and FADs but not LADs may indicate different drivers of speciation versus extinction in the hominin lineage. These results are consistent with Grove's (2012) hypothesis that speciation in the hominin lineage is driven by climate whereas extinction is driven primarily by biotic processes, including competition between species (contra Foley, 
1994). However, there is evidence that climate change plays an important role in extinctions across other African lineages (Faith and Behrensmeyer, 2013; Faith, 2014), raising the possibility that the mechanisms underlying turnover patterns may be dependent on the ecological characteristics of the lineage in question (see also Patterson et al., 2013).

Furthermore, delays likely to have occurred between the drivers of evolutionary events, the events themselves, and evidence of those events (i.e., FADs) create complications that arise in any study of evolutionary cause and effect. These lag effects may have resulted from the spatial diversity of African environments, particularly in how physical geography, tectonism, and other factors potentially influenced the expression of regional climate dynamics at local scales. Although further study of how East African climate history and geographic diversity interact is essential, our results emphasize that diverse regional records (eolian dust and sapropels) and local environmental indicators (records in sedimentary basins that were inhabited by hominins) show the predicted alternating pattern of high and low climate variability. Our focus on prolonged climate phases predicted to endure $>192 \mathrm{kyr}$, moreover, improves the chances that evolutionary events (i.e., originations) and their proliferation, spread, and preservation in sedimentary records will have occurred within the same intervals of climate variability.

It is inevitable that the ages of these evolutionary benchmarks will change with new discoveries. The null models show, however, that the current associations across the entire series of evolutionary events are unlikely to be observed by random chance, which includes random error in establishing the chronology of evolutionary events. This implies a causal relationship between climate variability and evolutionary change. At this point, our findings imply that critical transitions in hominin evolution were associated with prolonged rises in climate 
variability, consistent with the hypothesis that such events signified adaptive responses to environmental instability.

\section{Figure 6 here]}

Figure 6 presents a visual summary of the principal findings relating aspects of African hominin evolution to the prolonged phases of high climate variability. A distinct connection exists between long-term high variability and the current timing of major evolutionary milestones. In fact, the association is perfect with respect to existing information concerning the origin of hominin genera in Africa, the onset of major stone tool technologies, the first appearance of Homo sapiens, and the two most prominent dispersals of the genus Homo. That the key markers of African hominin evolution, represented in Figure 5, currently fall in the lengthiest phases of amplified wet-dry variability further suggests a robust causal connection. The wet and arid intervals of each $~ 20$-kyr precessional cycle are governed by monsoon intensity, which causes continual shifting of seasonal rainfall. The relationship between seasonality and orbital-scale climate variability is an important one. In the light of long-term climate variability, it is apparent that although seasonal fluctuations operate at the scale of individual lifetimes, gene pools persist and change in the context of long-term inconsistency in the timing and degree of seasonality-i.e., changes in the length, intensity, and patterning of rainy and dry seasons in the case of tropical Africa. While seasonal monsoons are the engine of climate variability, the inconsistency of seasonal rainfall over a precessional time scale, and the packaging of this variation in longer phases of alternating low and high climate variability, inevitably had a potent influence on resource landscapes, continually reshaping them and causing disparities in adaptive conditions encountered by lineages of organisms and their gene pools over 
time. This observation is the basis of the variability selection model portrayed in Figure 1, and conveys the logic behind linking climate variability with the problem of how instability in adaptive settings can be overcome-i.e., how adaptability may evolve over time.

\section{Utility of the model illustrated by CV Stage $\mathrm{H} 2$}

The value of the alternating high/low variability model is that it offers testable hypotheses about the environmental and adaptive context of African human evolution over the course of the past five million years. The framework can be used to examine evidence of habitat and landscape variability in long stratigraphic sections or within a region, and the conditions in which hominins or particular behaviors became apparent (or died out) in those stratigraphic or regional records. Although it has not been our focus here, Stage H2 is particularly compelling to examine $(358-50 \mathrm{ka})$. It is the longest predicted phase of high climate variability over the past two million years. Situated in it are: the emergence of the Middle Stone Age, including early development of symbolic material culture and a rise in technological innovation (e.g., McBrearty and Brooks, 2000), the origination of Homo sapiens, the origin of the Late Stone Age, the expansion of human population size and genetic diversity, and the initial dispersal of $H$. sapiens beyond Africa (Table 2). This suite of events strongly suggests a widening of adaptability, fulfilling all four criteria defined at the beginning of this paper: an increased ability to endure, thrive in, and spread to new habitats, and to respond in novel ways to the surroundings.

Although long stratigraphic records for this time frame in East Africa are rare, the sedimentary sequences of the Omo Kibish Fm, southern Ethiopia, and the post-Olorgesailie Fm in the Olorgesailie Basin, southern Kenya, provide initial clues about climate variability during 
this period. In both areas, repeated intervals of base level rise and sedimentation are interrupted by times of deep erosional incision. McDougall et al. (2005) make the case that phases of sedimentation and incision between $198 \mathrm{ka}$ and $104 \mathrm{ka}$ reflect intensified monsoon cycles of precipitation and aridity on a precessional time scale, correlated with the formation of Mediterranean sapropels. At Olorgesailie the period from $~ 320$ to $50 \mathrm{ka}$ is also characterized by repeated valley cutting and filling, which was likely related to climatic control over large shifts in base level compared to earlier times in the southern Kenya Rift (Behrensmeyer et al., 2002). The combination of magnified climate variability as predicted by the high/low model, initial evidence that at least East African hominins did indeed encounter strong environmental variability, and evidence of critical evolutionary markers of increased adaptability suggests that the proposed link between climate instability and key developments in human evolution is robust for this latter period of African human evolution.

Adaptability: does it evolve?

Environmental variability occurs at all temporal scales: from microseconds within the cellular environment, to daily, annual, and decadal scales in the environments of long-lived organisms, and from millennial to orbital time scales over which the longer-term evolution of gene pools occurs. A capacity to adjust to this variability-i.e., to changes in the variance, tempo, and predictability of the surroundings - may thus be found at diverse biological levels, manifested in genomic organization and variation, in the behavior of cells, tissue and organ systems, and in the adaptive versatility of individuals, social groups, populations, and species lineages. 
Due to this wide spectrum of temporal and biological scales, a variety of approaches has been taken to address the problem of how adaptability may arise. Although adaptability may well evolve via selection in response to temporal and spatial heterogeneity (e.g., Potts, 1996a, b; Kingston, 2007; Donges et al., 2011), it is also possible that adaptability is expressed merely as a by-product of time (e.g., the potential for adaptability results from the accumulation of random genetic variations) or as an artifact of selection (e.g., adaptability is the sum result of habitatspecific selection in diverse habitats). Adaptability has also been considered a pre-existing function in organisms due to conserved cellular processes that affect an organism's development (Kirshner and Gerhart, 2005). Numerous definitions have been advanced for the related concept of evolvability, several of which focus on regulatory processes that influence an organism's potential to evolve (Kirshner and Gerhart, 1998; Pigliucci, 2008).

The approach adopted here looks to how the larger outcomes of African hominin evolutionary history — phylogenetic events, behavioral milestones, and dispersals — were temporally associated with climate dynamics. The correlation of any single event with a phase of high climate variability does not provide evidence of the exact causal processes that were involved (e.g., Behrensmeyer, 2006). Nonetheless, the alternating high/low variability model defines a testable framework relevant to the adaptive context of African hominin evolution. The findings here are consistent with the model of variability selection shown in Figure 1, in that this hypothetical process requires sustained periods of inconsistent environmental conditions (reflected by prolonged high climate variability) such that combinations of genes favoring adaptive versatility can take hold and proliferate in the gene pool, a process potentially interrupted by too rapid a return to more stable environmental (and selective) conditions. This integrative process of assembling the genomic material favoring adaptability in the face of 
environmental variability could only be feasible across time spans far exceeding a lifetime or generation.

\section{Conclusion}

Variability selection is a process by which combinations of genes (coding and regulatory) and their interactive effects are favored-i.e., increased in the gene pool—due to heightened variability in environmental conditions. The resulting adaptations enhance the versatility of an organism in how it interacts with its surroundings, enabling it to generate or call upon an enlarged variety of adaptive options (e.g., an ability to alter its resource choices or breadth, or to diversify its grouping or social behavior) and to buffer the impacts of unpredictable or novel environmental conditions.

The resulting increase in adaptability may be expressed in any of the four ways listed at the outset of this article. Two important expectations for identifying this process are: (1) key adaptations evolved and spread during intervals of high climate and landscape variability, and (2) those adaptations enabled the lineage to adjust to novel environments. Both of these expectations are borne out in the analyses offered here.

Based on current evidence, the novel suites of behavior signaled by the onset and spread of the Oldowan, Acheulean, Middle Stone Age, and Late Stone Age in East Africa corresponded with long-duration phases of high environmental variability, as did the first appearances of each of the three genera Australopithecus (A. anamensis), Paranthropus (P. aethiopicus), and early Homo. According to the VS paradigm, each of these evolutionary benchmarks would reflect a ratcheting up of adaptability relative to the adaptive potentials that had evolved in other hominin 
Potts and Faith: High/low climate variability

lineages. Although hominin biogeographic history is bound to have been complex, the two main dispersals from Africa to Eurasia-expansion of Homo and expansion of H. sapiens - also coincided with protracted phases of heightened wet-dry variability in eastern Africa. These two dispersals led to the colonization of highly diverse environmental settings, consistent with the idea that adaptive versatility was promoted in Oldowan-bearing Homo ("Out of Africa I") and technologically-diverse Homo sapiens (“Out of Africa II”) during African high variability phases. These observations are consistent with VS as a viable process by which adaptability evolved over the course of African hominin evolution.

Independent of variability selection, the analyses presented here define and test a model of climate dynamics related to variation in orbital eccentricity, characterized by repeated alternation of high and low climate variability for tropical East Africa over the past five million years. The age boundaries for high and low climate variability stages provide an explicit set of hypotheses concerning the structure and timing of East African climate dynamics, which can be tested against long stratigraphic outcrop and drill-core records. Positive correlations of eolian dust and sapropel variance with predicted shifts in climate variability provide strong confirmation of the model. At the same time, regional variations in the expression of environmental dynamics can be expected to occur due to unique tectonic histories and geomorphological settings in different sedimentary basins. The climate variability model provides an initial basis on which local and regional environmental histories of East African early hominins can be compared and contrasted with a general model of climate dynamics.

Alternation of high and low climate variability implies that numerous transitions occurred leading from environmental/resource stability to instability. Each of these transitions provided a test of adaptability and the persistence of survival strategies. The most prolonged eras of 
magnified environmental variability may have offered the most likely opportunities for novel strategies of adaptive versatility and cultural buffering to take hold and proliferate. The evolution of adaptability thus becomes an overarching theme in the overall narrative of human evolution.

\section{Acknowledgements}

RP wishes to thank R.X. Zhu, C.L. Deng, and Y.X Pan, Institute of Geology and Geophysics, Chinese Academy of Sciences, Beijing, for support, collaboration on the Nihewan Basin research, and X. Qinghai for pollen analyses; and Peter deMenocal for discussion of the high/low climate variability model, for sharing data, and inspiring the tests of the model here. The Olorgesailie research is a collaborative project of the National Museums of Kenya and Smithsonian Institution; RP thanks Drs. I.O. Farah, E.N. Mbua, F.K. Manthi, and P. Kiura for their long-term support. Much gratitude also goes to Olorgesailie project collaborators A.K. Behrensmeyer, R.B. Owen, and A.L. Deino for paleoenvironmental, stratigraphic, and geochronological studies. We thank J.B. Clark for assistance in producing the figures and logistical support for the research reported here. RP also gratefully acknowledges support from the Peter Buck Fund for Human Origins Research, NSF HOMINID Program grant BCS0218511, and the Ruth and Vernon Taylor Foundation. JTF is supported by a University of Queensland Postdoctoral Research Fellowship. Some of the ideas developed here came to fruition through discussions with participants of the Smithsonian's Evolution of Terrestrial Ecosystems (ETE) workshops on Community Assembly and Disassembly. We thank Ariane Burke and Matt Grove for the invitation to contribute this paper; two anonymous reviewers who 
Potts and Faith: High/low climate variability

contributed valuable comments; and Matt Grove and Mark Teaford for permitting us to revise the manuscript in response to recent discoveries of earliest known Homo and stone artifacts. 


\section{References}

Antón, S.C., 2003. A Natural History of Homo erectus. Yrbk. Phys. Anthropol. 46, 126-170.

Antón, S.C., 2012. Early Homo: who, when, and where. Curr. Anthropol. 53, S278-S298.

Antón, S.C., Swisher, C.C., III, 2004. Early dispersals of Homo from Africa. A. Rev. Anthropol. $33,271-296$.

Antón, S.C., Potts, R., Aiello, L., 2014. Evolution of early Homo: an integrated biological perspective. Science 345, 45. Doi: $10.1126 /$ science.1236828

Asfaw, B., White, T.D., Lovejoy, O., Latimer, B., Simpson, S., Suwa, G., 1999. Australopithecus garhi: a new species of early hominid from Ethiopia. Science 284, 629-635.

Ashley, G.M., 2007. Orbital rhythms, monsoons, and playa lake response, Olduvai Basin, equatorial East Africa (ca. 1.85-1.74 Ma). Geology 35, 1091-1094.

Behrensmeyer, A.K., 2006. Climate change and human evolution. Science 311, 476-478.

Behrensmeyer, A.K., 2008. Paleoenvironmental context of the Pliocene A.L. 333 "First Family" hominin locality, Hadar Formation, Ethiopia. In: Quade, J., Wynn, J.G. (Eds.), The Geology of Early Humans in the Horn of Africa. Geological Society of America Special Paper 446, pp. 203-214.

Behrensmeyer, A.K., Todd, N.E., Potts, R., McBrinn, G.E., 1997. Late Pliocene faunal turnover in the Turkana Basin, Kenya and Ethiopia. Science 278, 1589-1594.

Behrensmeyer, A.K., Potts, R., Deino, A.L., Ditchfield, P., 2002. Olorgesailie, Kenya: a million years in the life of a rift basin. In: Renaut, R.W., Ashley, G.M. (Eds.), Sedimentation in Continental Rifts. SEPM Special Publication 73, pp. 97-106. 
Potts and Faith: High/low climate variability

Bobe, R., 2006. The evolution of arid ecosystems in eastern Africa. J. Arid Environ. 66, 564584.

Bobe, R., Behrensmeyer, A.K., 2004. The expansion of grassland ecosystems in Africa in relation to mammalian evolution and the origin of the genus Homo. Palaeogeogr. Palaeoclimatol. Palaeoecol. 207, 399-420.

Bobe, R., Leakey, M.G., 2009. Ecology of Plio-Pleistocene mammals in the Omo-Turkana Basin and the emergence of Homo. In: Grine, F.E., Fleagle, J.G., Leakey, R.E. (Eds.), The First Humans: Origin and Early Evolution of the Genus Homo. Springer, Netherlands, pp. $173-184$.

Bonnefille, R., 1984. Palynological research at Olduvai Gorge. Nat. Geogr. Soc. Res. Rep. 17, 227-243.

Brown, F.H., McDougall, I., Gathogo, P.N., 2013. Age ranges of Australopithecus species, Kenya, Ethiopia, and Tanzania, In: Reed, K.E., Fleagle, J.G., Leakey, R.E. (Eds.), The Paleobiology of Australopithecus. Springer, Netherlands, pp. 7-20.

Campisano, C.J., 2007. Tephrostratigraphy and Hominin Paleoenvironments of the Hadar Formation, Afar Depression, Ethiopia. Ph.D. dissertation, Rutgers University.

Campisano, C.J., Feibel, C.S., 2007. Connecting local environmental sequences to global climate patterns: evidence from the hominin-bearing Hadar Formation, Ethiopia. J. Hum. Evol. $53,515-527$.

Campisano, C.J., Feibel, C.S., 2008. Depositional environments and stratigraphic summary of the Pliocene Hadar Formation at Hadar, Afar Depression, Ethiopia. In: Quade, J., Wynn, J.G. (Eds.), The Geology of Early Humans in the Horn of Africa. Geological Society of America Special Paper 446, pp. 179-201. 
Chui, C-H., Bajwa, T., Homiski, R., Potts, R., 2006. Environmental dynamics on an evolutionary time scale can shape the genetic basis of an organism's adaptability: insights from $C$. elegans. Am. J. Phys. Anthropol. S42.

Deino, A.L., 2011. ${ }^{40} \mathrm{Ar} /{ }^{39} \mathrm{Ar}$ dating of Laetoli, Tanzania, in: Harrison, T.M. (Ed.), Paleontology and Geology of Laetoli: Human Evolution in Context. Springer, Netherlands, pp. 77-97. Deino, A.L., 2012. ${ }^{40} \mathrm{Ar} /{ }^{39} \mathrm{Ar}$ dating of Bed I, Olduvai Gorge, Tanzania, and the chronology of early Pleistocene climate change. J. Hum. Evol. 63, 251-73.

Deino, A., Potts, R., 1990. Single crystal 40Ar/39Ar dating of the Olorgesailie Formation, southern Kenya rift. J. Geophys. Res. 95 (B6), 8453-8470.

Deino, A.L., Domínguez-Rodrigo, M., Luque, L., 2006a. ${ }^{40} \mathrm{Ar} /{ }^{39} \mathrm{Ar}$ dating of the Pleistocene Peninj Group, Lake Natron, Tanzania. EOS Trans. AGU Fall Meeting S87, Abstract V53C-1771.

Deino, A.L., Kingston, J.D., Glen, J.M., Edgar, R.K., Hill, A., 2006b. Precessional forcing of lacustrine sedimentation in the late Cenozoic Chemeron Basin, Central Kenya Rift. Earth Planet. Sci. Lett. 247, 41-60.

deMenocal, P.B., 1995. Plio-Pleistocene African climate. Science 270, 53-59. deMenocal, P.B., 2004. African climate change and faunal evolution during the PliocenePleistocene. Earth Planet. Sci. Lett. 220, 3-24.

deMenocal, P.B., 2011. Climate and human evolution. Science 331, 540-541. deMenocal, P.B., Bloemendal, J., 1995. Plio-Pleistocene climatic variability in subtropical Africa and the paleoenvironment of hominid evolution. In: Vrba, E.S., Denton, G.H., Partridge, T.C., Burkle, L.H. (Eds.), Paleoclimate and Evolution, with Emphasis on Human Origins. Yale University Press, New Haven, CT, pp. 262-288. 
Dennell, R., Roebrooks, W., 2005. An Asian perspective on early human dispersals from Africa. Nature 438, 1099-1104.

Dennell, R.W., 2010. The colonization of "Savannahstan": issues of timing (s) and patterns of dispersal across Asia in the Late Pliocene and Early Pleistocene. In: Norton, C.J., Braun, D.R. (Eds.), Asian Paleoanthropology: From Africa to China and Beyond. Springer, Dordrecht, pp. 7-30.

Domínguez-Rodrigo, M., Pickering, T.R., Baquedano, E., Mabulla, A., Mark, D.F., Musiba, C., Bunn, H.T., Uribelarrea, D., Smith, V., Diez-Martin, F., Pérez-González, A., Sánchez, P., Santonja, M., Barboni, D., Gidna, A., Ashley, G., Yravedra, J., Heaton, J.L., Arriaza, M.C., 2013. First Partial Skeleton of a 1.34-Million-Year-Old Paranthropus boisei from Bed II, Olduvai Gorge, Tanzania. PLoS ONE 8(12): e80347.

Doi:10.1371/journal.pone.0080347

Donges, J.F., Donner, R.V., Trauth, M.H., Marwan, N., Schellnhuber, H.-J., Kurths, J., 2011. Nonlinear detection of paleoclimate-variability transitions possibly related to human evolution. Proc. Natl. Acad. Sci. USA 108, 20423-20428.

Dupont-Nivet, G., Sier, M., Campisano, C.J., Arrowsmith, J.R., DiMaggio, E., Reed, K., Lockwood, C., Franke, C., Hüsing, S., 2008. Magnetostratigraphy of the eastern Hadar Basin (Ledi-Geraru research area, Ethiopia) and implications for hominin paleoenvironments. In: Quade, J., Wynn, J.G. (Eds.), The Geology of Early Humans in the Horn of Africa. Geological Society of America Special Paper 446, 67-85.

Emeis, K.-C., Sakamoto, T., Wehausen, R., Brumsack, H.-J., 2000. The sapropel record of the eastern Mediterranean Sea e results of Ocean Drilling Program Leg 160. Palaeogeogr. Palaeoclimatol. Palaeoecol. 158, 371-395. 
Faith, J.T., 2014. Late Pleistocene and Holocene mammal extinctions on continental Africa. Earth Sci. Rev. 128, 105-121.

Faith, J.T., Behrensmeyer, A.K., 2013. Climate change and faunal turnover: testing the mechanics of the turnover-pulse hypothesis with South African fossil data. Paleobiology 39, 609-627.

Feibel, C.S., Brown, F., McDougal, I., 1989. Stratigraphic context of fossil hominids from the Omo Group deposits: northern Turkana Basin, Kenya and Ethiopia. Am. J. Phys. Anthropol. 78, 595-622.

Feibel, C.S., Harris, J.M., Brown, F.H., 1991. Palaeoenvironmental context for the late Neogene of the Turkana Basin. In: Harris, J.M. (Ed.), Koobi Fora Research Project, Volume 3: The Fossil Ungulates: Geology, Fossil Artiodactyls, and paleoenvironments. Clarendon, Oxford, pp. 321-370.

Feibel, C.S., Lepre, C.J., Quinn, R., 2009. Stratigraphy, correlation, and age estimates for fossil from Area 123, Koobi Fora. J. Hum. Evol. 57, 112-122.

Ferring, R., Oms, O., Agustı', J., Berna, F., Nioradze, M., Shelia, T., Tappen, M., Vekua, A., Zhvania, D., Lordkipanidze, D., 2011. Earliest human occupations at Dmanisi (Georgian Caucasus) dated to 1.85-1.78 Ma. Proc. Natl. Acad. Sci. USA 108, 10432-10436.

Foley, R.A., 1994. Speciation, extinction and climatic change in hominid evolution. J. Hum. Evol. 26, 275-289.

Gathogo, P.N., Brown, F.H., 2006. Revised stratigraphy of Area 123, Koobi Fora, Kenya, and new age estimates of its fossil mammals, including hominins. J. Hum. Evol. 51, 471-479. 
Gliganic, L.A., Jacobs, Z., Roberts, R.G., Domínguez-Rodrigo, M., Mabulla, A.Z.P., 2012. New ages for Middle and Later Stone Age deposits at Mumba rockshelter, Tanzania: optically stimulated luminescence dating of quartz and feldspar grains. J. Hum. Evol. 62, 533-547.

Gotelli, N.J., 2001. Research frontiers in null model analysis. Glob. Ecol. Biogeogr. 10, 337343.

Gotelli, N.J., Graves, G.R., 1996. Null models in ecology. Smithsonian Institution Press, Washington.

Grine, F.E., Ungar, P.S., Teaford, M.F., El-Zaatari, S., 2006. Molar microwear in Praeanthropus afarensis: evidence for dietary stasis through time and under diverse paleoecological conditions. J. Hum. Evol. 51, 297-319.

Grove, M., 2011a. Speciation, diversity, and Mode 1 technologies: the impact of variability selection. J. Hum. Evol. 61, 306-319.

Grove, M., 2011b. Change and variability in Plio-Pleistocene climates: modelling the hominin response. J. Archaeol. Sci. 38, 3038-3047.

Grove, M., 2012. Amplitudes of orbitally induced climatic cycles and patterns of hominin speciation. J. Archaeol. Sci., 39, 3085-3094.

Grove, M., 2014 (in press). Palaeoclimates, plasticity, and the early dispersal of Homo sapiens. Quatern. Int. doi: 10.1016/j.quaint.2014.08.019.

Harmand, S., Lewis, J.E., Feibel, C.S., Lepre, C.J., Prat, S., Lenoble, A., Boës, X., Quinn, R.L., Brenet, M., Arroyo, A., Taylor, N., Clément, S., Daver, G., Brugal, J.-P., Leakey, L., Mortlock, R.A., Wright, J.D., Lokorodi, S., Kirwa, C., Kent, D.V., Roche, H., 2015. 3.3million-year-old stone tools from Lomekwi 3, West Turkana, Kenya. Nature 521, 310315. 
Harmon, E.H., Behrensmeyer, A.K., Kimbel, W.H., Johanson, D.C., 2003, Preliminary taphonomic analysis of hominin remains from A.L. 333, Hadar Formation, Ethiopia. Paleoanthropology Society Abstracts http://www.paleoanthro.org/static/pdfs/abst2003.pdf

Hay, R.L., 1976. The Geology of Olduvai Gorge. University of California Press, Los Angeles. Hilgen, F.J., Abdul Aziz, H., Krijgsman, W., Langereis, C.G., Lourens, L.J., Meulenkamp, J.E., Raffi, I., Steenbrink, J., Turco, E., van Vugt, N., Wijbrans, J.R., Zachariasse, W.J., 1999. Present status of the astronomical (polarity) time-scale for the Mediterranean Late Neogene. Phil. Trans. Math. Phys. Engineer. Sci. 357, 1931-1947.

Huffman, O.F., Zaimb, Y., Kappelman, J., Ruez Jr., D.R., de Vos, J., Rizal, Y., Aziz, F., Hertler, C., 2006. Relocation of the 1936 Mojokerto skull discovery site near Perning, East Java. J. Hum. Evol. 50, 431-451

Jaeger, J.-J., 1976. Les Rongers (Mammalia, Rodentia) du Pleistocene inférieur d'Olduvai Bed I (Tanzanie). In: Savage, R.J.G., Coryndon, S.C. (Eds.), Iere partie: Les Murides. Fossil Vertebrates of Africa, vol. 4, pp. 58-120.

Johanson, D.C., Taieb, M., Coppens, Y., 1982. Pliocene hominids from the Hadar formation, Ethiopia (1973-1977): stratigraphic, chronologic, and paleoenvironmental contexts, with notes on hominid morphology and systematics. Am. J. Phys. Anthropol. 57, 373-402.

Joordens, J.C.A., Vonhof, H.B., Feibel, C.S., Lourens, L.J., Dupont-Nivet, G., van der Lubbe, J.H.J.L., Sier, M.J., Davies, G.R., Kroon, D., 2011. An astronomically-tuned climate framework for hominins in the Turkana Basin. Earth Planet. Sci. Lett. 307, 1-8.

Joordens, J.C.A., Dupont-Nivet, G., Feibel, C.S., Spoor, F., Sier, M.J., van der Lubbe, J.H.J.L., Kellberg Nielsen, T., Knul, M.V., Davies, G.R., Vonhof, H.B., 2013. Improved age 
control on early Homo fossils from the Upper Burgi Member at Koobi Fora, Kenya. J. Hum. Evol. 65, 731-745.

Kimbel, W.H., Rak, Y., Johanson, D.C., 2004. The Skull of Australopithecus afarensis. Oxford University Press, New York.

Kingston, J.D., 2007. Shifting adaptive landscapes: progress and challenges in reconstructing early hominid environments. Yrbk. Phys. Anthropol. 50, 20-58.

Kingston, J.D., Deino, A.L., Edgar, R.K., Hill, A., 2007. Astronomically forced climate change in the Kenyan Rift Valley 2.7-2.55 Ma: implications for the evolution of early hominin ecosystems. J. Hum. Evol. 53, 487-503.

Kirshner, M., Gerhart, J., 1998. Evolvability. Proc. Natl. Acad. Sci. USA 95, 8420-8427.

Kirshner, M., Gerhart, J., 2005. The Plausibility of Life. Yale University Press, New Haven.

Kutzbach, J.E., 1981. Monsoon climate of the early Holocene: climate experiment with Earth's orbital parameters for 9000 years ago. Science 214, 59-61.

Laskar, J., Fienga, A., Gastineau, M, Manche, H., 2011. La2010: a new orbital solution for the long-term motion of the Earth. Astronomy and Astrophysics 532, A89 1-15.

Leakey, M.G., Feibel, C.S., McDougall, I., Ward, C., Walker, A., 1998. New specimens and confirmation of an early age for Australopithecus anamensis. Nature 393, 62-66.

Leakey, M.G., Spoor, F., Brown, F.H., Gathogo, P.N., Kiarie, C., Leakey, L.N., McDougall, I., 2001. New hominin genus from eastern Africa shows diverse middle Pliocene lineages. Nature 410, 433-440.

Leakey, M.G., Spoor, F., Dean, M.C., Feibel, C.S., Antón, S.C., Kiarie, C., Leakey, L.N., 2012. New fossils from Koobi Fora in northern Kenya confirm taxonomic diversity in early Homo. Nature 488, 201-204. 
Lepre, C.J., Quinn, R.L., Joordens, J.C.A., Swisher, C.C., III, Feibel, C.S., 2007. PlioPleistocene facies environments from the KBS Member, Koobi Fora Formation: implications for climate controls on the development of lake-margin hominin habitats in the northeast Turkana Basin (northwest Kenya). J. Hum. Evol. 53, 504-514.

Lepre, C.J., Roche, H., Kent, D.V., Harmand, S., Quinn, R.L., Brugal, J.-P., Texier, J.-P., Lenoble, A., Feibel, C.S., 2011. An earlier origin for the Acheulean. Nature 477, 82-85.

Levins, R., 1968. Evolution in Changing Environments. Princeton University Press, Princeton. Lockwood, C.A., Kimbel, W.H., Johanson, D.C., 2000. Temporal trends and metric variation in the mandibles and dentition of Australopithecus afarensis. J. Hum. Evol. 39, 23-55.

Lordkipanidze, D., Ponce de León, M.S., Margvelashvili, A., Rak, Y., Rightmire, G.P., Vekua, A., Zollikofer, C.P.E., 2013. A complete skull from Dmanisi, Georgia, and the evolutionary biology of early Homo. Science 342, 326-331.

Lourens, L.J., Antonarakou, A., Hilgen, F., Van Hoof, A.A.M., Vergnaud-Grazzini, C., Zachariasse, W.J., 1996. Evaluation of the Plio-Pleistocene astronomical timescale. Paleoceanography $11,391-413$.

Manley, B.F.J., 1997. Randomization, Bootstrap and Monte Carlo Methods in Biology. Chapman and Hall, London.

Marshall, C.R., 1990. Confidence intervals on stratigraphic ranges. Paleobiology 16, 1-10. Maslin, M.A., Christensen, B., 2007. Tectonics, orbital forcing, global climate change, and human evolution in Africa. J. Hum. Evol. 53, 443-464.

Maslin, M.A., Trauth, M.H., 2009. Plio-Pleistocene East African pulsed climate variability and its influence on early human evolution. In: Grine, F.E., Leakey, R.E., Fleagle, J.G. (Eds.), The First Humans: Origins of the Genus Homo. Springer, New York, pp. 151-158. 
McBrearty, S., Brooks, A.S., 2000. The revolution that wasn't: a new interpretation of the origin of modern human behavior. J. Hum. Evol. 39, 453-563.

McDougall, I., Brown, F.H., Fleagle, J., 2005. Stratigraphic placement and age of modern humans from Kibish, Ethiopia. Nature 433, 733-736.

Morgan, L.E., Renne, P.R., 2008. Diachronous dawn of Africa's Middle Stone Age: new 40Ar/39Ar ages from the Ethiopian Rift. Geology 36, 967-970.

Owen, R.B., Potts, R., Behrensmeyer, A.K., Ditchfield, P., 2008. Diatomaceous sediments and environmental change in the Pleistocene Olorgesailie Formation, southern Kenya Rift Valley. Palaeogeogr. Palaeoclimatol. Palaeoecol. 269, 17-37.

Patterson, D.B., Faith, J.T., Bobe, R., Wood, B., 2013. Regional diversity patterns in African bovids, hyaenids, and felids during the past 3 million years: the role of taphonomic bias and implications for the evolution of Paranthropus. Quatern. Sci. Rev. 96, 9-22.

Pigliucci, M., 2008. Is evolvability evolvable? Nat. Rev. Genet. 9, 75-82.

Polkras, E.M., Mix, A.C., 1987. Earth's precession cycle and Quaternary climatic change in tropical Africa. Nature 326, 486-487.

Potts, R., 1996a. Humanity's Descent: the Consequences of Ecological Instability. William Morrow, New York.

Potts, R., 1996b. Evolution and climate variability. Science 273, 922-923.

Potts, R., 1998. Variability selection in hominid evolution. Evol. Anthropol. 7, 81-96.

Potts, R., 2001. Mid-Pleistocene environmental change and human evolution. In: Barham, L., Robson-Brown, K. (Eds.), Human Roots: Africa and Asia in the Middle Pleistocene. Western Academic Press, Bristol, pp. 5-21. 
Potts, R., 2002. Complexity and adaptability in human evolution. In: Goodman, M., Moffat, A. (Eds.), Probing Human Origins. American Academy of Arts and Sciences, Cambridge, MA, pp. 33-57.

Potts, R., 2012. Environmental and behavioral evidence pertaining to the evolution of early Homo. Curr. Anthropol. 53(S6), S299-S317.

Potts, R., 2013. Hominin evolution in settings of strong environmental variability. Quatern. Sci. Rev. 73, 1-13.

Potts, R., Behrensmeyer, A.K., Ditchfield, P., 1999. Paleolandscape variation in early Pleistocene hominid activities: members 1 and 7, Olorgesailie Formation, Kenya. J. Hum. Evol. 37, 747-788.

Potts, R., Behrensmeyer, A.K., Deino, A.L., Ditchfield, D., Clark, J., 2004. Small midPleistocene hominin associated with East African Acheulean technology. Science 305, $75-78$.

Quinn, R.L., Lepre, C.J., Wright, J.D., Feibel, C.S., 2007. Paleogeographic variations of pedogenic carbonate d13C values from Koobi Fora, Kenya: implications for floral compositions of Plio-Pleistocene hominin environments. J. Hum. Evol. 53, 560-573.

R Core Development Team, 2013. R: A language and environment for statistical computing. R Foundation for Statistical Computing, Vienna, Austria.

Reed, K.E., 1997. Early hominid evolution and ecological change through the African PlioPleistocene. J. Hum. Evol. 32, 289-322.

Reed K.E., 2008. Paleoecological patterns at the Hadar hominin site, Afar Regional State, Ethiopia. J. Hum. Evol. 54, 743-768. 
Rossignol-Strick, M., 1983. African monsoons, an immediate climate response to orbital insolation. Nature 304, 46-49.

Ruddiman, W.F., 2001. Earth's Climate: Past and Future. W.H. Freeman, New York.

Sachs, J.P., Repeta, D.J., 1999. Oligotrophy and nitrogen fixation during eastern Mediterranean sapropel events. Science 286, 2485-2488.

Sakamoto, T., Janecek, T., Emeis, K.C., 1998. Continuous sedimentary sequences of the Eastern Mediterranean Sea: composite depth sections of ODP Leg 160. Scientific Results of the Proceedings of the Ocean Drilling Program 160, 37-60.

Semaw, S., Rogers, M.J., Quade, J., Renne, P.R., Butler, R.F., Domínguez-Rodrigo, M., Stout, D., Hart, W.S., Pickering, T., Simpson, S.W., 2003. 2.6-Million-year-old stone tools and associated bones from OGS-6 and OGS-7, Gona, Afar, Ethiopia. J. Hum. Evol. 45, 169177.

Signor, P.W., Lipps, J.H., 1982. Sampling bias, gradual extinction patterns, and catastrophes in the fossil record. Geological Society of America Special Publication 190, 291-296.

Soares, P., Alshamali, F., Pereira, J.B., Fernandes, V., Silva, N.M., Alfonso, C., Costa, M.D., Musilová, E., Macaulay, V., Richards, M.B., Černy, V., Pereira, L., 2012. The expansion of mtDNA haplogroup L3 within and out of Africa. Molec. Biol. Evol. 29, 915-927.

Solé, R., Goodwin, B., 2000. Signs of Life. Basic Books, New York.

Spoor, F., Leakey, M.G., Gathogo, P.N., Brown, F.H., Antón, S.C., McDougall, I., Kiarie, C., Manthi, F.K., Leakey, L.N., 2007. Implications of new early Homo fossils from Ileret, east of Lake Turkana, Kenya. Nature 448, 688-691. 
Spoor, F., Gunz, P., Neubauer, S., Steizer, S., Scott, N., Kwekason, A., Dean, M.C., 2015. Reconstructed Homo habilis type $\mathrm{OH} 7$ suggests deep-rooted species diversity in early Homo. Nature 519, 83-86.

Suwa, G., White, T.D., Howell, F.C., 1996. Mandibular postcanine dentition from the Shungura Formation, Ethiopia: Crown morphology, taxonomic allocations, and Plio-Pleistocene hominid evolution. Am. J. Phys. Anthropol. 101, 247-282.

Swisher, C.C., III, Curtis, G.H., Jacob, T., Getty, A.G., Suprijo, A., Widiasmoro, 1994. Age of the earliest known hominids in Java, Indonesia. Science 263, 1118-1121.

Trauth, M.H., Maslin, M.A., Deino, A.L., Strecker, M.R., 2005. Late Cenozoic moisture history of East Africa. Science 309, 2051-2053.

Trauth, M.H., Maslin, M.A., Deino, A.L., Strecker, M.R., Bergner, A.G.N., Dühnforth, M., 2007. High- and low-latitude forcing of Plio-Pleistocene East African climate and human evolution. J. Hum. Evol. 53, 475-486.

Trauth, M.H., Maslin, M.A., Deino, A.L., Junginger, A., Lesoloyiae, M., Odada, E.O., Olago, D.O., Olaka, L.A., Strecker, M.R., Tiedemann, R., 2010. Human evolution in a variable environment: the amplifier lakes of Eastern Africa. Quatern. Sci. Rev. 29, 2981-2988.

van Dam, J.A., Abdul Aziz, H., Sierra, M.A.A., Hilgen, F.J., van den Hoek-Ostende, L.W., Lourens, L.J., Mein, P., van der Meulen, A.J., Pelaez-Campomanes, P., 2006. Longperiod astronomical forcing of mammal turnover. Nature 443, 687-691.

Villmoare, B., Kimbel, W.H., Seyoum, C., Campisano, C.J., DiMaggio, E., Rowan, J., Braun, D.R., Arrowsmith, J.R., Reed, K.E., 2015. Early Homo at 2.8 Ma from Ledi-Geraru, Afar, Ethiopia. Science 347, 1352-1355. 
Vrba, E.S., 1985. Environment and evolution: alternative causes of the temporal distribution of evolutionary events. S. Afr. J. Sci. 81, 229-236.

Vrba, E.S., 1988. Late Pliocene climatic events and hominid evolution. In: Grine, F.E. (Ed.), Evolutionary History of the 'Robust' Australopithecines. Aldine de Gruyter, New York, pp. $405-426$.

Vrba, E.S., 1995. On the connections between paleoclimate and evolution. In: Vrba, E.S., Denton, G.H., Partridge, T.C., Burckle, L.H. (Eds.), Paleoclimate and Evolution with Emphasis on Human Origins. Yale University Press, New Haven, CT, pp. 24-45.

Walter, R.C., 1994. Age of Lucy and the First Family: single-crystal ${ }^{40} \mathrm{Ar} /{ }^{39} \mathrm{Ar}$ dating of the Denen Dora and lower Kada Hadar Members of the Hadar Formation, Ethiopia. Geology $22,6-10$.

Wehausen, R., Brumsack, H.-J., 1998. The formation of Pliocene Mediterranean sapropels: constraints from high-resolution major and minor element studies. In: Robertson, A.H.F., Emeis, K.-C., Richter, C., Camerlenghi, A. (Eds.), Proceedings ODP, Scientific Results 160, 207-218. Ocean Drilling Program, College Station, TX.

Wehausen, R., Brumsack, H.-J., 1999. Cyclical variations in the chemical composition of eastern Mediterranean Pliocene sediments: a key for understanding sapropel formation. Marine Geol. 153, 161-176.

White, T.D., WoldeGabriel, G., Asfaw, B., Ambrose, S., Beyene, Y., Bernor, R.L., Boisserie, J.R., Currie, B., Gilbert, H., Haile-Selassie, Y., Hart, W.K., Hlusko, L.J., Howell, F.C., Kono, R.T., Lehmann, T., Louchart, A., Lovejoy, C.O., Renne, P.R., Saegusa, H., Vrba, E.S., Wesselman, H., Suwa, G., 2006. Asa Issie, Aramis and the origin of Australopithecus. Nature 440, 883-889 
White, T.D., Asfaw, B., Beyene, Y., Haile-Selassie, Y., Lovejoy, C.O., et al. 2009. Ardipithecus ramidus and the paleobiology of early hominids. Science $326,75-86$.

Wood, B., 1991. Koobi Fora Research Project, Volume 4, Hominid Cranial Remains. Clarendon, Oxford.

Wood, B., Constantino, P., 2007. Paranthropus boisei: fifty years of evidence and analysis. Yrbk. Phys. Anthropol. 50, 106-132

Woods, R.J., Barrick, J.E., Cooper, T.F., Shrestha, U., Kauth, M.R., Lenski, R.E., 2011. Secondorder selection for evolvability in a large Escherichia coli population. Science 331, 14331436.

Wu, F., Fang, X., Ma, Y, Hermann, M., Mosbrugger, V., An, Z., Miao, Y., 2007. PlioQuaternary stepwise drying of Asia: evidence from a 3-Ma pollen record from the Chinese Loess Plateau. Earth Planet. Sci. Lett. 257, 160-169.

Zhu, R.X., Potts, R., Xie, F., Hoffman, K.A., Deng, C.L., Shi, C.D., Pan, Y.X., Wang, H.Q., Shi, R.P., Wang, Y.C., Shi, G.H., Wu, N.Q., 2004. New evidence regarding the earliest human presence at high northern latitudes in northeast Asia. Nature 431, 559-562.

Zhu, R.X., Potts, R., Pan, Y.X., Yao, H.T., Lü, L.Q., Zhao, X., Gao, X., Chen, L.W., Gao, F., Deng, C.L., 2008. Early evidence of the genus Homo in East Asia. J. Hum. Evol. 55, 1075-1085. 


\section{Figure captions}

Figure 1. A conceptual model of variability selection, based on earlier publications (Potts 1996a, b, 1998a, b), showing change in a gene pool (left column) due to selective advantages in specific habitats (e.g., adaptations favored in either arid or moist environments) versus the relative advantage of adaptable phenotypes (e.g., adaptations enabling the ability to buffer and adjust to change) during a long interval of high climate variability (right column). Variability selection is a hypothetical process by which the adaptability of biological systems becomes enhanced in response to variable conditions of natural selection over time and space related to heightened environmental instability. Climate is based on Mediterranean sapropel spectral reflectance data from $\sim 2.1$ to $2.3 \mathrm{Ma}$ (Sakamoto et al., 1998), corresponding to part of CV Stage H17 (see Table 1).

Figure 2. The relationship between the change $(\Delta)$ in mean eccentricity and the change in the standard deviation of $(\mathrm{A})$ dust flux $(\mathrm{r}=0.775, \mathrm{p}<0.001)$ and $(\mathrm{B})$ sapropel reflectance $(\mathrm{r}=0.561$, $\mathrm{p}<0.001$ ) across successive time bins of high/low variability over the last 5 million years (data from Table 1). Solid lines represent the reduced major axis (RMA) regression. In both cases, measured variation in the environmental record tracks the magnitude of change in mean eccentricity on which the alternating high/low climate variability model is based. 
Figure 3. The FADs of East African hominin lineages (red =Homo, green = Paranthropus, blue = Australopithecus) relative to the eight prolonged phases of high climate variability (left), compared to a single iteration of the null model where the FADs have been randomized over the last 5 Myrs (right). Stars indicate those cases where the age range of the FAD overlaps with a prolonged high CV stage.

Figure 4. Null model results indicating the number of evolutionary events randomly associated with prolonged phases of high variability for (A) hominin FADs, (B) hominin LADs, (C) technological and biogeographic milestones, and (D) hominin FADs - constrained so that FAD of a species may occur only during the known temporal range of its genus. Arrows and red bars indicate the empirical observation (Table 2).

Figure 5. Majuanguo (Nihewan Basin) pollen data, showing the stratigraphic positions of archeological sites, 1.66 to $1.36 \mathrm{Ma}$ (data compilation by X. Qinghai, Hebei Normal University, and R.X. Zhu and C.L. Deng, Institute of Geology and Geophysics, Beijing).

Figure 6. Association between the eight longest eras of predicted high climate variability (shaded horizontal bars) and East African first/last appearance datums (FADs, LADs) of hominin genera and species, key technological innovations (earliest known appearances of the Oldowan, Acheulean, Middle Stone Age, Late Stone Age), and dispersals (early Homo and H. sapiens). The bottom and top of the shaded horizontal bars represent the ages of these longest-duration high variability stages, as indicated in Table 1 . Vertical color bars represent the age ranges of well-established species of East African hominins for the past 5 million years. 

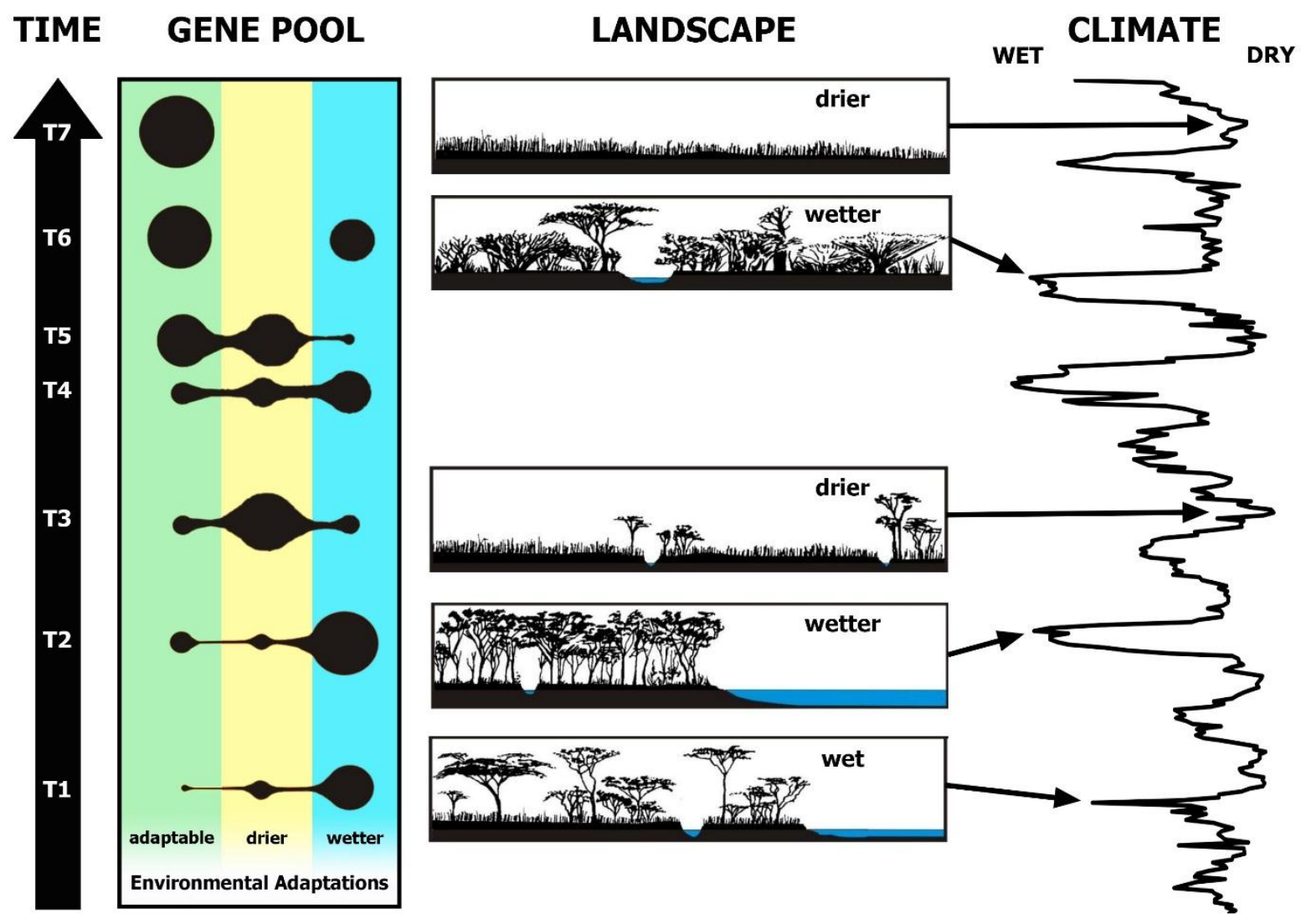
Potts and Faith: High/low climate variability
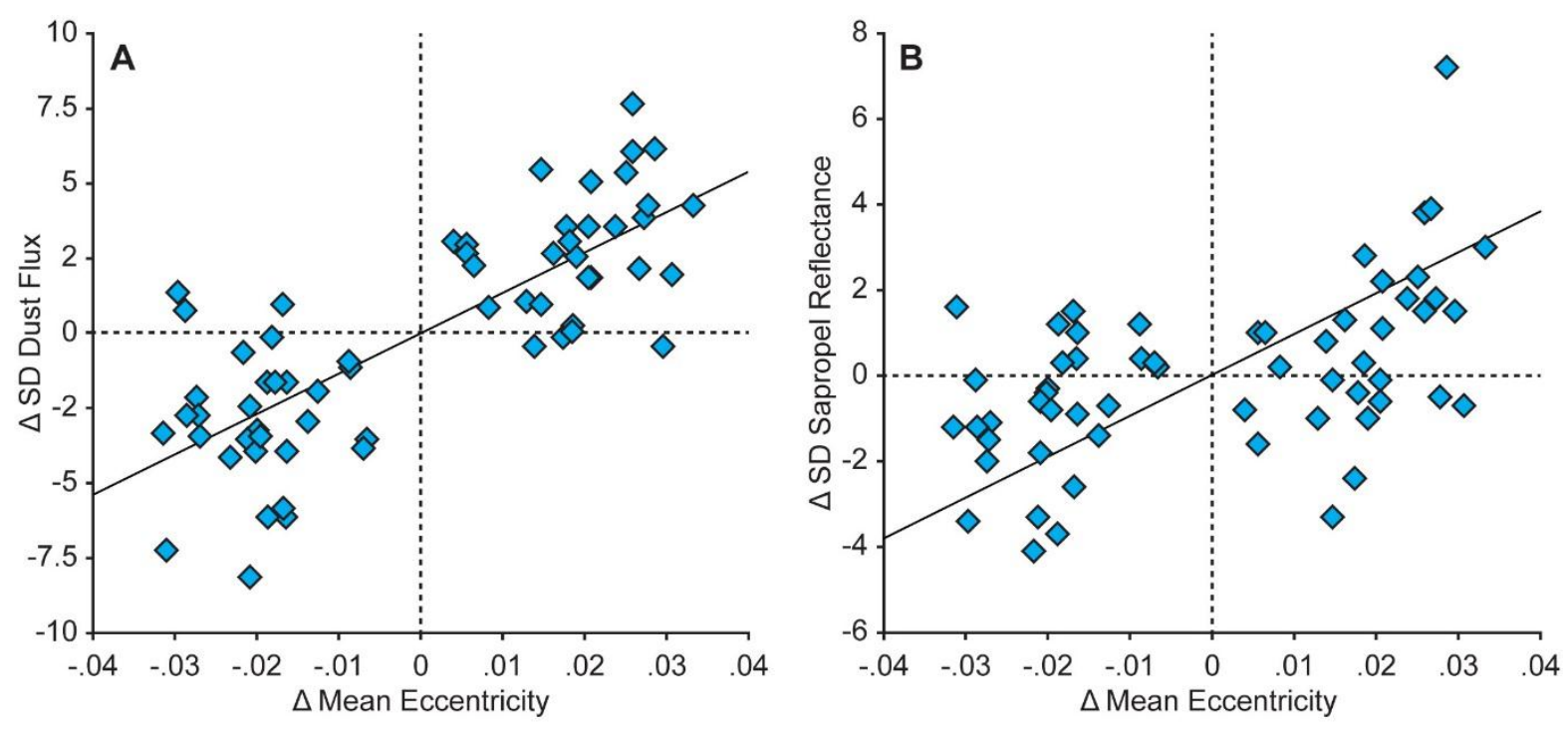
Potts and Faith: High/low climate variability
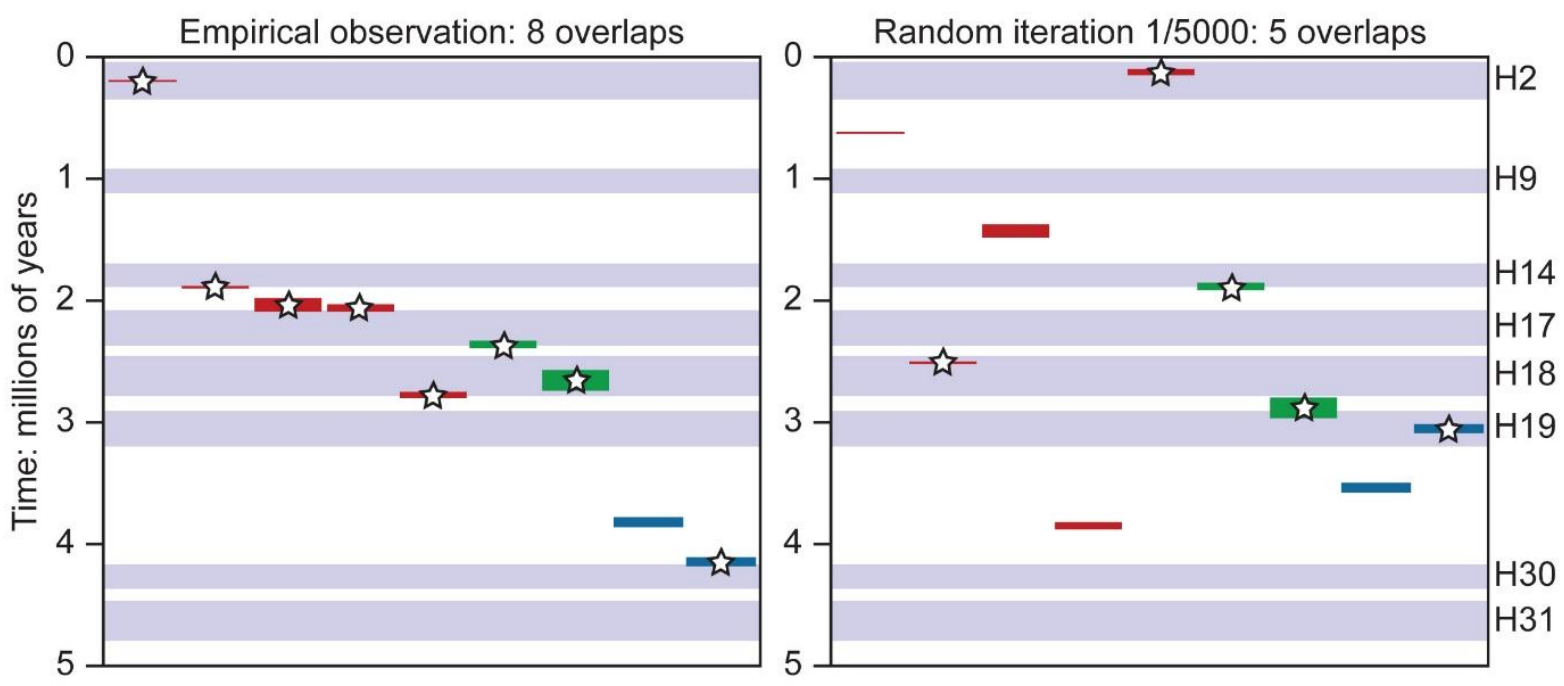
Potts and Faith: High/low climate variability
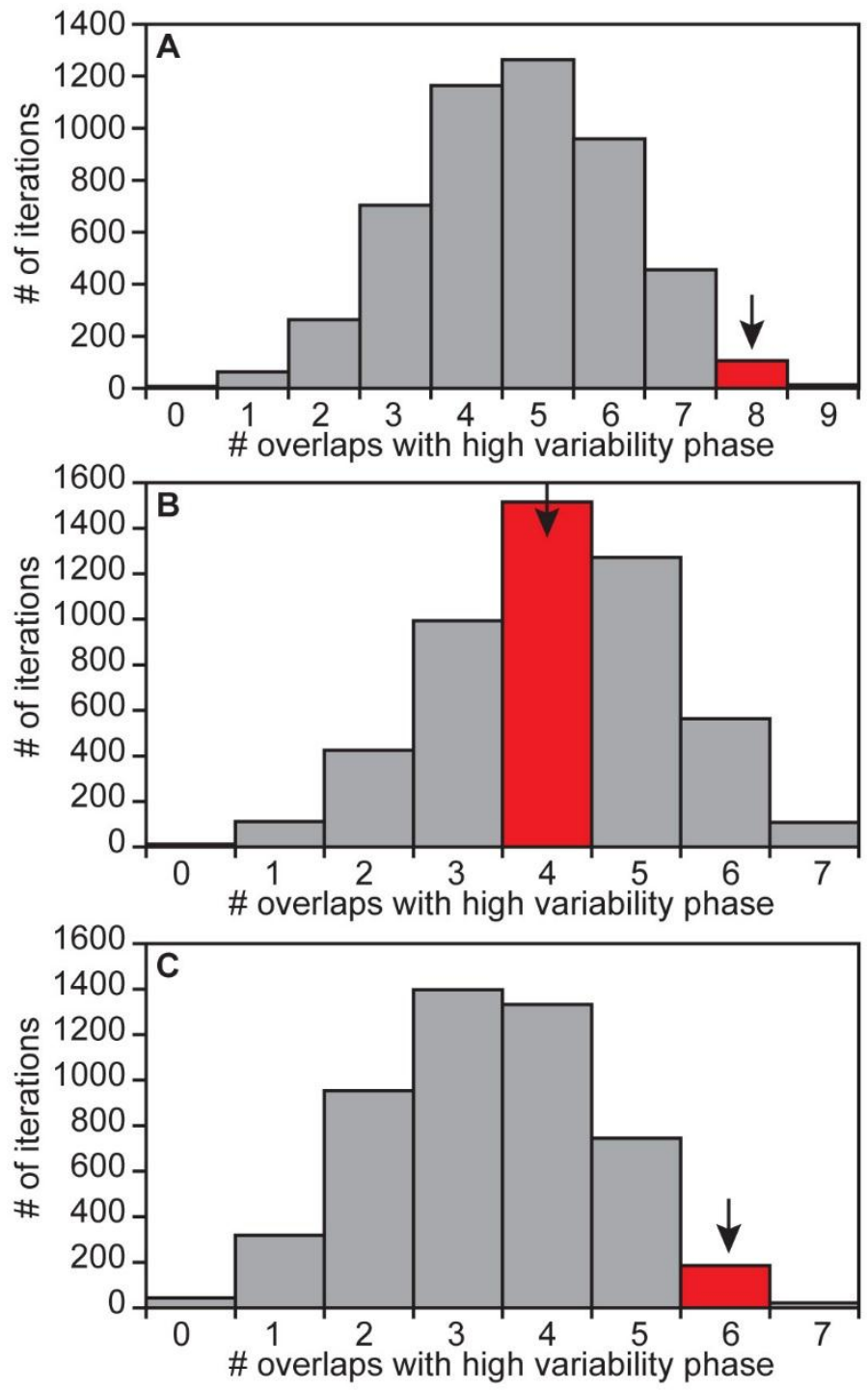


\section{Nihewan Basin (NE Asia) Fossil Pollen}

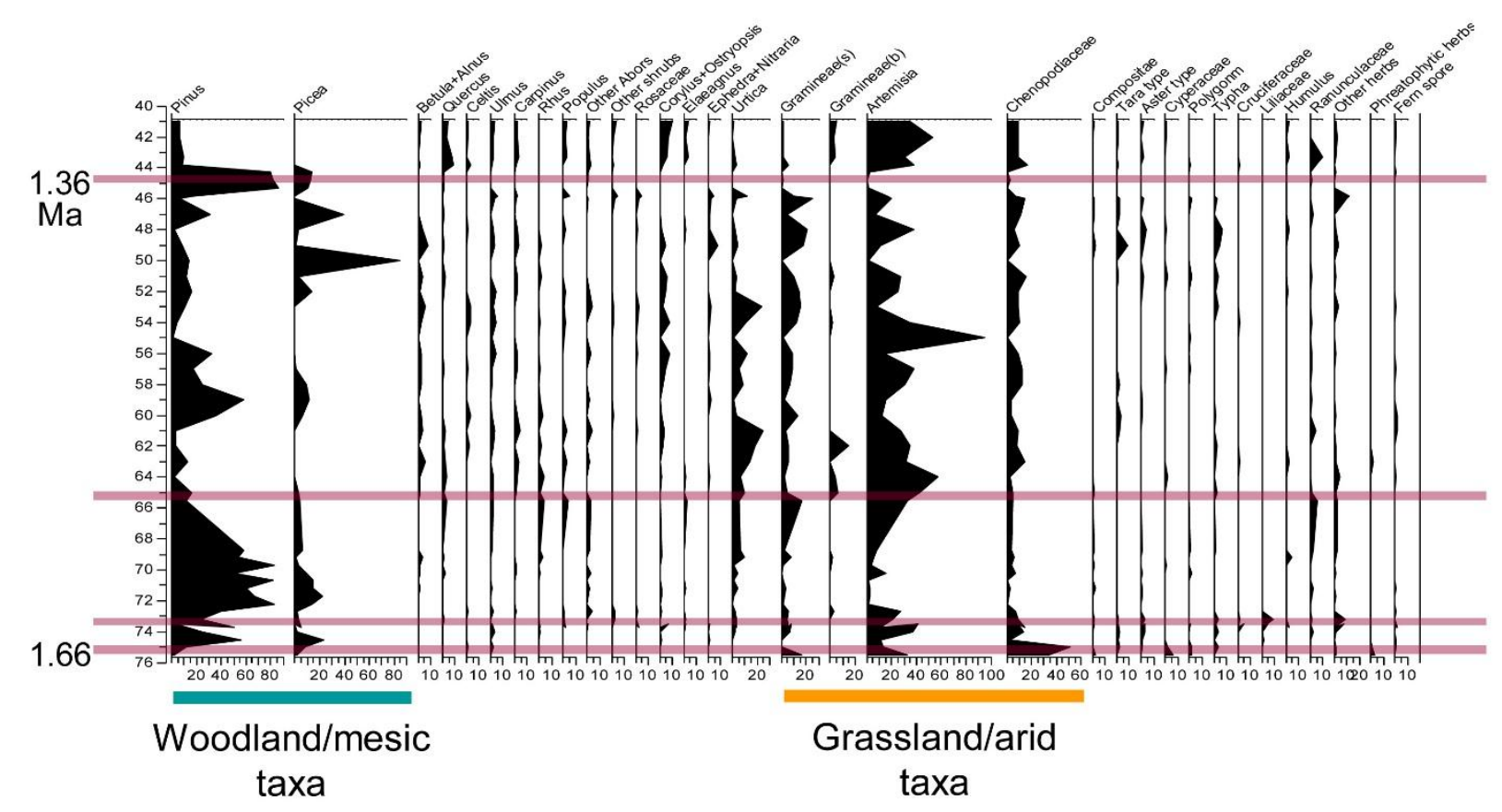


Potts and Faith: High/low climate variability

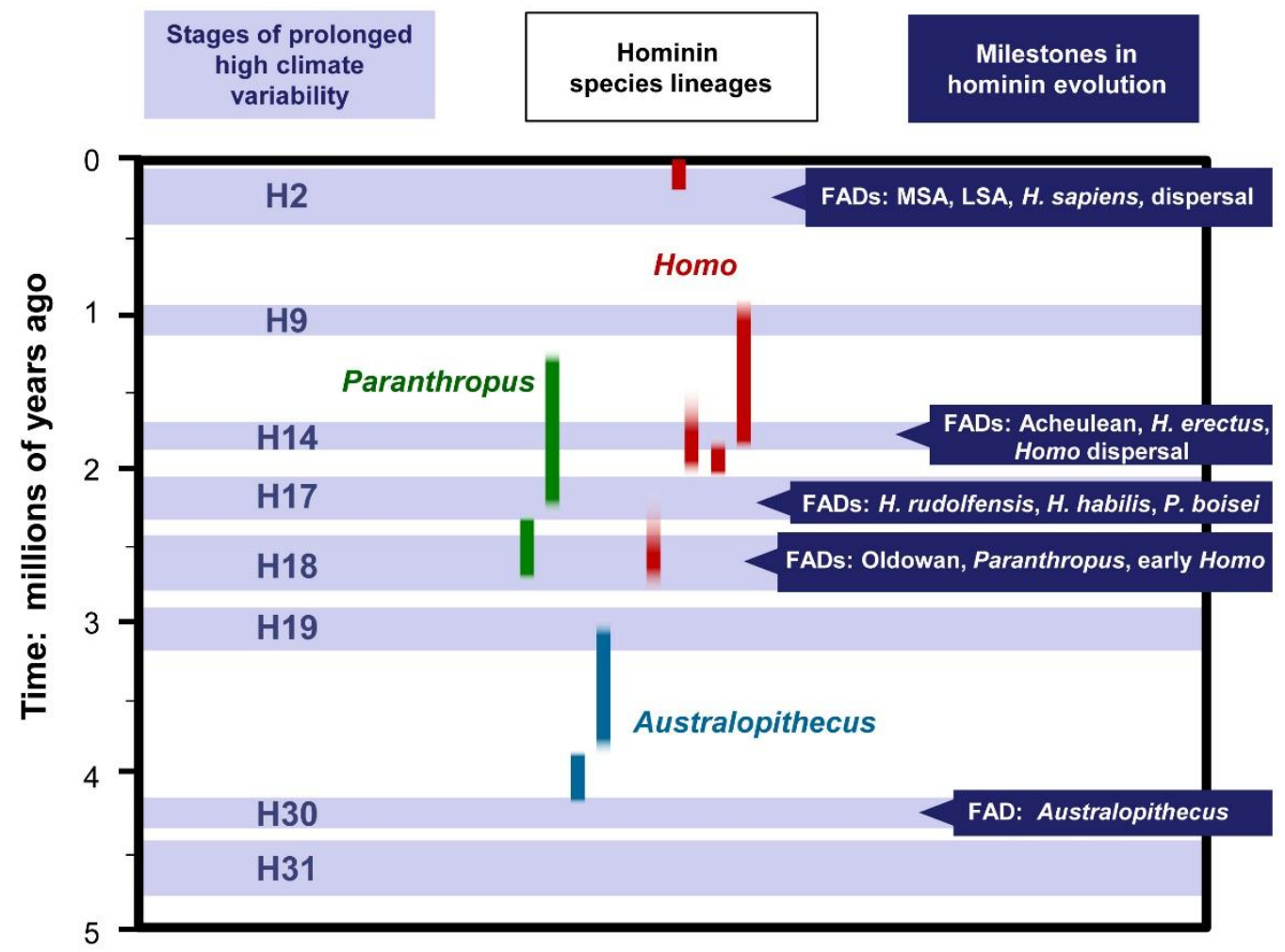




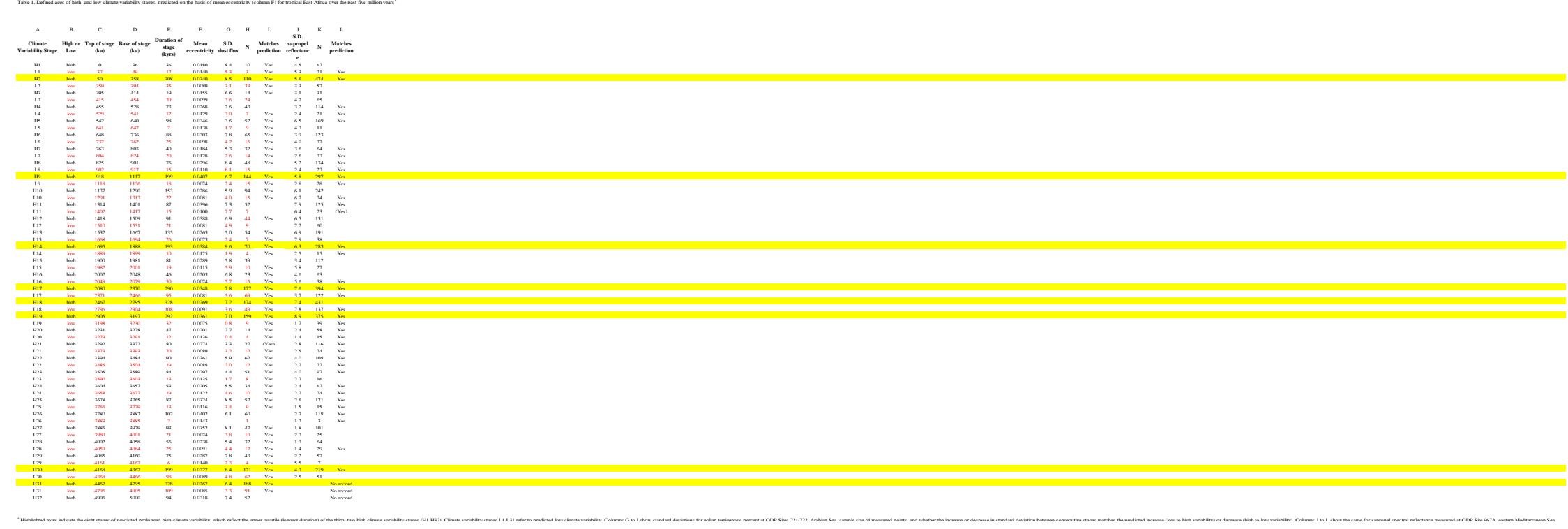


Table 2. First appearance datums (FADs) and last appearance datams (LADs) of hominin species in East Africa and ages for the appearance of key technological and biogeographic milestones ${ }^{a}$

\section{Speciation and extinction events}

\begin{tabular}{|c|c|c|c|}
\hline Species & $\mathrm{FAD}$ & LAD & Reference \\
\hline Homo sapiens & $0.2(\mathrm{H} 2)$ & $N / A$ & McDougall et al., 2005 \\
\hline African Homo erectus & $1.89(\mathrm{~L} 14)$ & $0.9(\mathrm{H} 8)$ & Antón, 2012; Potts et al., 2004 \\
\hline Homo habilis ${ }^{\mathrm{b}}$ & $2.09(\mathrm{H} 17)$ & $1.44(H 12)$ & Antón, et al., 2014 \\
\hline Homo rudolfensis ${ }^{\mathrm{b}}$ & $2.09(\mathrm{H} 17)$ & $1.78(\mathrm{H} 14)$ & Antón, et al., 2014 \\
\hline Early Homo sp. & $2.35(\mathrm{H} 17)$ & - & $\begin{array}{l}\text { Kimbel et al., 1996; Campisano, } \\
2012\end{array}$ \\
\hline Paranthropus boisei & $2.3(\mathrm{H} 17)$ & $1.2(\mathrm{H} 10)$ & $\begin{array}{l}\text { Suwa et al., 1997; Deino et al., } \\
2006 \text { b; Wood and Constantino, } \\
2007\end{array}$ \\
\hline Paranthropus aethiopicus & $2.72(\mathrm{H} 18)$ & $2.3(\mathrm{H} 17)$ & Wood and Constantino, 2007 \\
\hline Australopithecus afarensis & $3.85(\mathrm{H} 26)$ & $2.95(\mathrm{H} 19)$ & $\begin{array}{l}\text { Haileab and Brown, 1992; Grine et } \\
\text { al., 2006, Kimbel and Delezene, } \\
2009\end{array}$ \\
\hline Australopithecus anamensis & $4.2(\mathrm{H} 30)$ & $3.9(\mathrm{H} 27)$ & $\begin{array}{l}\text { Leakey et al., 1998; White et al., } \\
2006\end{array}$ \\
\hline \multicolumn{4}{|c|}{ Technological and biogeographic events } \\
\hline LSA technology & $>50 \mathrm{ka}(\mathrm{H} 2)$ & & Diez-Martín et al. 2009 \\
\hline H. sapiens Out of Africa & $\sim 70$ ka (H2) & & Behar et al. 2008 \\
\hline MSA technology & 285 ka (H2) & & Morgan and Renne, 2008 \\
\hline Acheulean technology & $1.76 \mathrm{Ma}(\mathrm{H} 14)$ & & Lepre et al. 2011 \\
\hline Early $H$. erectus Out of Africa & $1.85 \mathrm{Ma}(\mathrm{H} 14)$ & & Ferring et al., 2011 \\
\hline Oldowan technology & $2.58 \mathrm{Ma}(\mathrm{H} 18)$ & & Semaw et al. 2003 \\
\hline
\end{tabular}

${ }^{a}$ Events corresponding to a prolonged phase of elevated climatic variability, >192 kyr (Table 1), are indicated in bold.

${ }^{\mathrm{b}}$ Regarding early Homo (Leakey et al., 2012), the FAD for H. rudolfensis is based on the maximum of the recalibrated age of KNM-ER 1470, i.e., 2.09-2.03 Ma (Joordens et al., 2013), a span that overlaps with two lengthy high variability stages $(\mathrm{H} 17, \mathrm{H} 16)$ and an intervening, brief low variability stage (L16). Homo habilis FAD is also based on the maximal age assigned to mandible KNM-ER 1802 (Joordens et al., 2013), considered to fall in the same morphological group as ER 1813 (Antón et al., 2014). 